DOE/EA-1025

\title{
ENVIRONMENTAL ASSESSMENT OF GENERAL-PURPOSE HEAT SOURCE SAFETY VERIFICATION TESTING
}

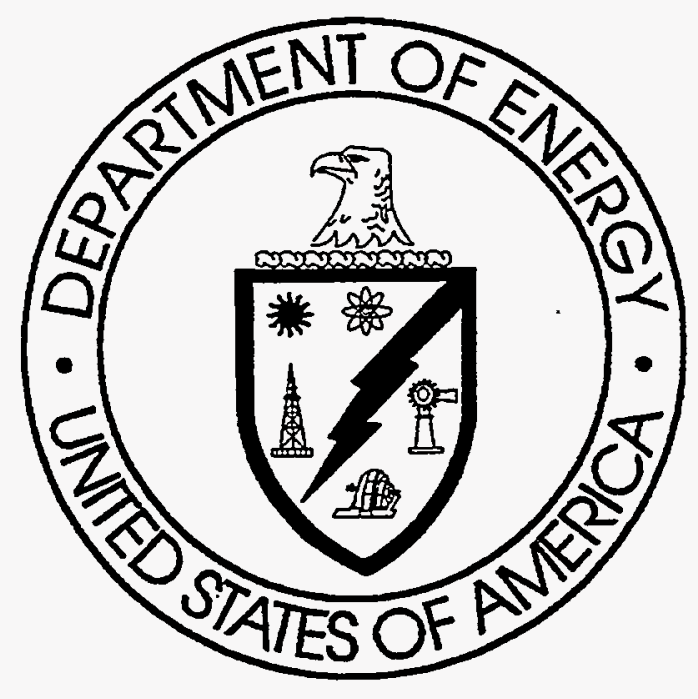

February 1995

U.S. Department of Energy Albuquerque Operations Office

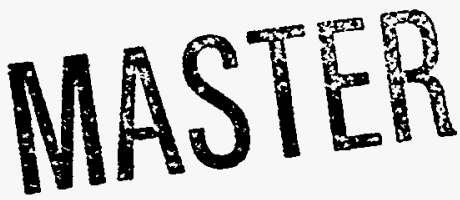




\section{DISCLAIMER}

This report was prepared as an account of work sponsored by an agency of the United States Government. Neither the United States Government nor any agency thereof, nor any of their employees, makes any warranty, express or implied, or assumes any legal liability or responsibility for the accuracy, completeness, or usefulness of any information, apparatus, product, or process disclosed, or represents that its use would not infringe privately owned rights. Reference herein to any specific commercial product, process, or service by trade name, trademark, manufacturer, or otherwise does not necessarily constitute or imply its endorsement, recommendation, or favoring by the United States Government or any agency thereof. The views and opinions of authors expressed herein do not necessarily state or reflect those of the United States Government or any agency thereof.

$\because \quad,-\cdot, \quad \therefore \quad$ m




\section{DISCLAIMER}

Portions of this document may be illegible in electronic image products. Images are produced from the best available original document. 


\section{U.S. Department of Energy \\ Finding of No Significant Impact \\ General-Purpose Heat Source (GPHS) \\ Radioisotope Thermoelectric Generator (RTG) \\ Safety Verification Testing \\ 10,000-Foot Sled Track Facility, \\ Sandia National Laboratories, Albuquerque, New Mexico}

\section{AGENCY: U.S. Department of Energy, Albuquerque Operations Office}

ACTION: Finding of No Significant Impact

DESCRIPTION OF THE PROPOSED ACTION: The Department of Energy (DOE) has prepared an Environmental Assessment (EA), DOE/EA-1025, to identify and evaluate potential environmental, safety, and health impacts associated with the Proposed Action to test GeneralPurpose Heat Source (GPHS) Radioisotope Thermoelectric Generator (RTG) assemblies at the Sandia National Laboratories 10,000-Foot Sled Track Facility, Albuquerque, New Mexico.

GPHS/RTGs provide a reliable source of electrical power on board some spacecraft during long duration space missions. These units are designed to convert heat from the natural decay of radioisotopic fuel into electrical power.

DOE has determined that existing experimental data on GPHS/RTG performance under accident explosion and impact scenarios does not encompass the full range of combinations of mission profiles, launch vehicles, and accident assumptions. A detailed safety assessment is required to support the flight safety certification process for any proposed RTG use. Based on the above, DOE has identified a need to test the GPHS/RTG to further quantify how well the assembly would limit the release of radioactive material after end-on and side-on impacts. All RTG testing is performed in conjunction with the Memorandum of Agreement between DOE and the National Aeronautics and Space Administration.

Sandia National Laboratories (SNL) will perform the tests at their sled track facility. The Los Alamos National Laboratory (LANL) will supply test equipment and the GPHS/RTG assemblies, and will perform the post-test analyses of the RTG sections. These LANL activities are analyzed in the 1979 LANL Environmental Impact Statement (EIS).

The Proposed Action includes the following elements:

(1) Round trip transportation of the sample GPHS/RTGs, and associated test equipment from LANL and transportation within SNL

(2) Preparing the SNL Sled Track Facility for the test series

(3) Assembly and verification of test equipment

(4) Performing up to nine collision impact tests of the GPHS/RTG sections

(5) Post-test recovery

(6) Analysis and disposition of test materials

(7) Removing and disposing of debris and waste from the area.

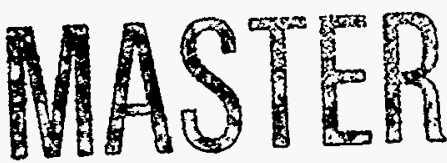


Six individual test articles (one half of a GPHS/RTG) would be accelerated by a rocket-propelled sled and impacted, end-on, into a concrete target. Three test articles would be impacted, sideon, by a thin sheet of aluminum accelerated by a rocket-propelled sled. Fuel simulants (molybdenum and depleted uranium) would be used in the RTG segments. The test articles would be heated to actual operating RTG temperatures prior to each test.

Damaged GPHS/RTG segments will be returned to LANL for examination and damage assessment, and the depleted uranium would be returned to the LANL special materials inventory. Transportation of equipment and depleted uranium will be in accordance with Department of Transportation (DOT) regulations. Waste materials would be managed and handled in accordance with SNL waste management procedures.

\section{ALTERNATIVES}

\section{No Action Alternative}

The No Action Alternative is defined as the condition where no testing of the GPHS/RTG would take place. This alternative does not satisfy DOE's Purpose and Need for Action. If proposed tests are not conducted, the Flight Safety Review would rely solely on modeling and data from previous STS tests, and the baseline safety database would not be updated or expanded with new experimental data which could benefit the launch safety review process for all future missions.

\section{Other Test Locations}

There are several other sled track facilities that potentially could conduct these tests. These locations are (1) the Los Alamos National Laboratory (LANL) PIXI Sled Track, Los Alamos, New Mexico; (2) Holloman Air Force Base Sled Track, Alamogordo, New Mexico; and (3) Terminal Effects Research and Analysis (TERA) Sled Track at New Mexico Institute of Mining and Technology, Socorro, New Mexico.

Conducting the tests at another location cannot be accomplished in the time frame required to provide needed input to the Flight Safety Review process. The alternative locations were dismissed from further consideration because they offer no significant environmental advantages over the proposed action.

\section{Substitutes for Depleted Uranium Oxide}

Hafnium oxide could be used to simulate plutonium oxide for the entire test series in place of depleted uranium oxide. Using it as a substitute for depleted uranium oxide was rejected on the basis that no database exists to make valid comparisons between damage to this material and plutonium oxide. 


\section{ENVIRONMENTAL IMPACTS}

The consequences of the Proposed Action include:

- Impacts to workers from residual depleted uranium present in the soil at the end of the Sled Track from previous tests

- Exposure to workers and the public to noise from rocket motors and collisions

- Exposure of workers and the public to air contaminants released by the rocket motors

- Production of waste materials

- Potential accidents

No significant impacts associated with the Proposed Action are anticipated. This Finding of No Significant Impact (FONSI) is based on the following factors, which are supported by the information and analyses in the EA.

\section{Radiological and Toxicological Impacts of Uranium}

The impacts of the Proposed Action would differ from ongoing activities at the Sled Track Facility only in that some sample GPHS/RTGs would contain depleted uranium oxide. These impacts could arise from an accident that would release depleted uranium oxide during one of the proposed tests (an extremely unlikely event) or as the result of uranium present in the soil as a residue from earlier Sled Track tests.

As fully evaluated in the EA, potential health effects from uranium compounds can arise from both chemical toxicity and radiation. The toxicological and radiological effects of the Proposed Action would not extend beyond the Sled Track Facility. Only personnel involved with the activities of the Proposed Action would be affected by these consequences, and the estimated risk for both radiological and toxicological effects on involved personnel are well below allowable limits.

\section{Noise Impacts}

Principal noise sources during the tests would be the rocket motor exhaust and the sound generated by the collisions of GPHS/RTGs with target surfaces. Estimates of the noise levels were made for the Sled Track Control Building, and the Gibson Boulevard entrance to KAFB. Since the time duration of the rocket motor is approximately one second, noise level standards are not exceeded for personnel at the sled track facility.

Noise levels at the Gibson Boulevard location probably would not be perceptible above the background noise conditions because of their short duration. 


\section{Air Quality Impacts}

The primary air quality effect is the release of the rocket exhaust products into the atmosphere. Total quantities of air contaminants are small compared with regulatory limits. Air emissions from the Proposed Action represents an increase over the ambient concentrations of less than one-tenth of one percent $(0.1 \%)$ of the Federal and New Mexico Ambient Air Quality Standards.

\section{Waste Disposal Impacts}

The solid and hazardous wastes that would be generated by the Proposed Action are essentially identical to wastes routinely generated by normal operations and tests at the Sled Track Facility. Existing procedures and temporary waste accumulation areas at the Sled Track Facility are adequate for the wastes that would be generated by the Proposed Action. The waste from the proposed test activities would be easily assimilated by the current waste handling procedures at the Sled Track Facility and SNL Waste Management Operations.

\section{Impacts from Potential Accidents}

The EA evaluated the following potential accidents (1) the release of depleted uranium oxide as a consequence of the total destruction of the sample GPHS/RTG, (2) a chemical spill of methanol, and (3) a transportation accident between LANL and SNL. These events are extremely unlikely to occur, and the consequences of these events are negligible. A total release of depleted uranium oxide would occur if the sample GPHS/RTG was totally destroyed. In such an event, exposures would increase, but they would still be about 300 times smaller than the allowable exposures of the DOE radiological health protection standards. If this release were to occur, neither the radiation impacts nor the chemical exposure impacts would pose health threats to workers or the general public.

Test preparations would require small amounts of organic solvents for miscellaneous purposes. A spill of the entire contents of a one gallon container represents situation that would have the greatest impact on personnel. Information in the EA demonstrates that even spillage of an entire container of any of these substances is unlikely to adversely impact the health of personnel or cause substantial release to the environment. In this situation, personnel would seek to limit the extent of the spill and call for the Hazardous Material Spill Response Team assistance. These actions would limit any adverse effects of exposure.

Test articles containing depleted uranium oxide would be transported between LANL and SNL by commercial vehicle. The EA investigated the impacts of an accident enroute. For a single trip, the likelihood of an accident would be approximately one accident in every 20,000 one-way trips. Therefore, an accident is unlikely. Even if an accident were to occur, it is unlikely that depleted uranium oxide would be dispersed into the environment. The material is chemically stable and transported in accordance with DOT regulations that specify packaging and container requirements. In addition, the shipping manifest would identify either LANL or SNL as the shipper. In the event of an accident, state or local law enforcement authorities would use the shipping manifest to notify LANL or SNL so that an emergency response team could be notified to respond to the scene of the accident. 


\section{Cumulative and Long-term Effects}

The proposed test program is expected to have a duration of approximately five months. Significant cumulative and long-term effects are not expected from the Proposed Action after testing is concluded. Except for the proposed use of depleted uranium oxide, the activities of the Proposed Action are no different than activities from normal Sled Track operations.

FINDING: Based on the analysis of impacts in the environmental assessment, the proposed testing of the General Purpose Heat Source Radioisotope Thermoelectric Generator at the Sandia National Laboratories/New Mexico 10,000 Foot Sled Track Facility would not significantly affect the quality of the human environment within the meaning of the National Environmental Policy Act, 42 U.S.C. 4321, et seq. Therefore, the Department is issuing this finding of no significant impact and an environmental impact statement is not required.

PUBLIC AVALABILITY: Copies of the EA (DOE/EA-1025) are available from

Kathleen A. Carlson, Manager

Kirtland Area Office

U.S. Department of Energy, Albuquerque Operations Office

5301 Central Avenue NE, Suite 1700

Albuquerque, New Mexico 87108

(505) $845-4094$

For further information regarding the DOE NEPA process, contact

Joseph F. Robbins

U.S. Department of Energy

Albuquerque Operations Office

P.O. Box 5400

Albuquerque, NM 87185-5400

(505) $845-4426$

Issued in Albuquerque, New Mexico this $13^{\text {th }}$ day of February, 1995.

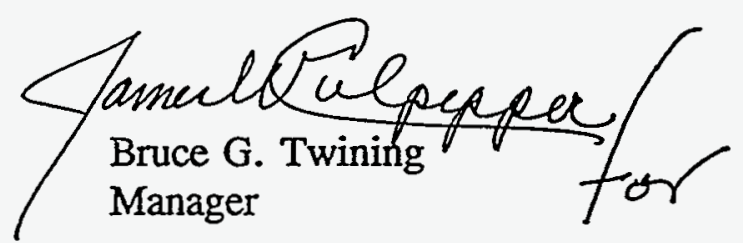


DOE/EA-1025

\section{ENVIRONMENTAL ASSESSMENT OF GENERAL-PURPOSE HEAT SOURCE SAFETY VERIFICATION TESTING}

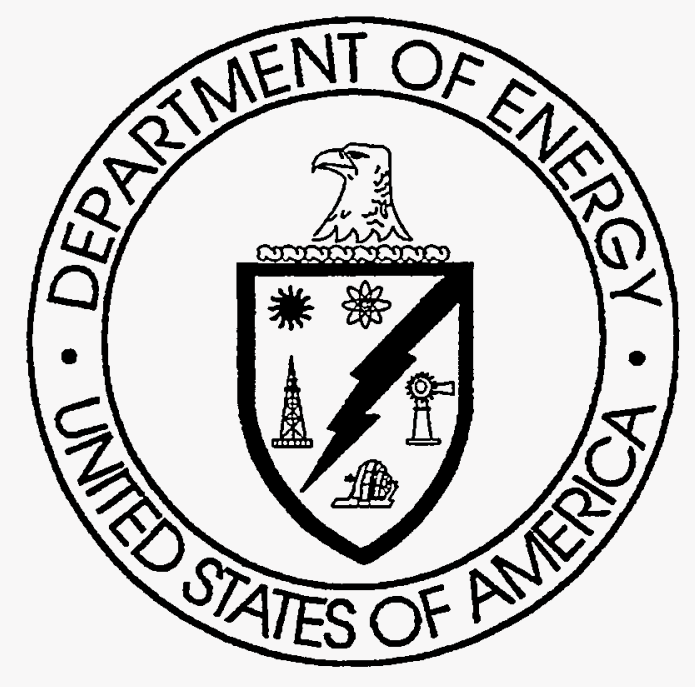

February 1995

U.S. Department of Energy Albuquerque Operations Office

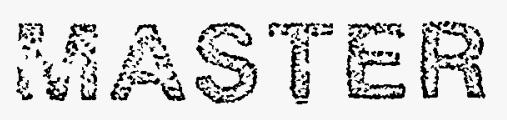


This page intentionally left blank. 


\section{EXECUTIVE SUMMARY}

This Environmental Assessment (EA) was prepared to identify and evaluate potential environmental, safety, and health impacts associated with the Proposed Action to test General-Purpose Heat Source (GPHS) Radioisotope Thermoelectric Generator (RTG) assemblies at the Sandia National Laboratories (SNL) 10,000-Foot Sled Track Facility, Albuquerque, New Mexico. RTGs are used to provide a reliable source of electrical power on board some spacecraft when solar power is inadequate during long duration space missions. These units are designed to convert heat from the natural decay of radioisotope fuel into electrical power. Impact test data are required to support DOE's mission to provide radioisotope power systems to NASA and other user agencies. The proposed tests will expand the available safety database regarding RTG performance under postulated accident conditions. Direct observations and measurements of GPHS/RTG performance upon impact with hard, unyielding surfaces are required to verify model predictions and to ensure the continual evolution of the RTG designs that perform safely under varied accident environments. The Proposed Action is to conduct impact testing of RTG sections containing GPHS modules with simulated fuel. End-On and Side-On impact test series are planned.

The End-On series would consist of two engineering tests using non-radioactive molybdenum GPHS fuel simulants and two test article tests using depleted uranium oxide fuel simulants. Each GPHS/RTG test article would be attached to a rocket-propelled sled and accelerated along the Sled Track to a specified speed. The test article would strike a concrete target placed at the end of the track.

The Side-On impact test series would include an engineering test and a test article test. The engineering test would use non-radioactive molybdenum GPHS fuel simulants, and the test article test would use depleted uranium oxide fuel simulants. Each test article would be placed in fixed position above the sled track. A thin sheet of aluminum would be attached to a rocket sled in such a way that the sheet would strike the article edge-on at a specified speed.

The purpose of this test series is to simulate two types of GPHS/RTG impact that might result from an accident near the launch pad. Once the two test series are completed, the damaged articles would be carefully examined to evaluate the effects of the impacts.

The Proposed Action includes preparing the Sled Track Facility, transporting GPHS/RTG test articles from their point of origin, Los Alamos National Laboratory (LANL), to the SNL Sled Track, preparing rocket sleds and the test area, firing up to 9 rocket sleds that would require a total of up to 75 small rocket motors, colliding the GPHS/RTG articles, collecting the articles for examination, removing and disposing of test debris from the area, and transporting the impacted GPHS/RTG modules back to LANL for evaluation and eventual reclamation or disposal. 
Alternatives considered include:

- The No Action Alternative, i.e. to not conduct the testing

- Conducting the testing at another location

- Using hafnium oxide in place of depleted uranium oxide

These alternatives do not satisfy Department of Energy's (DOE) Purpose and Need for Action. If the tests were not conducted, limited experimental data would be available regarding GPHS/RTG performance under certain launch configurations and accident environments. Absence of experimental impact data for a variety of accident environments could limit NASA's option to select RTGs as the source of electrical power for various future outerplanetary missions. The SNL 10,000-Foot Sled Track Facility is the only facility with a current capability to conduct the proposed tests. Facilities at other locations would require engineering modifications or a renegotiation of policy prohibiting testing using depleted uranium oxide. Conducting the impact tests at other locations would not offer significant environmental advantages over the proposed action using SNL facilities. Valid comparisons between hafnium oxide and the nuclear fuel to be used in actual RTGs cannot currently be made.

The consequences of these actions are examined in this EA. The environmental effects include:

- Impacts to workers from residual depleted uranium present in the soil at the End-On impact area from previous tests

- Exposure to workers and the public to noise from rocket motors and collisions

- Exposure of workers and the public to air contaminants released by the rocket motors, including carbon monoxide, lead, and other chemicals

- Production of waste materials

- Risks associated with transportation of test assemblies before and after impact between LANL and SNL

The effects of the Proposed Action would differ from ongoing activity at the Sled Track Facility only in that test articles would contain depleted uranium oxide. Radiological effects of the Proposed Action would not extend beyond the Sled Track Facility. Only personnel involved with the activities of the Proposed Action would be affected by these consequences, and they would be minimal. Noise and air quality effects to workers and the general public would be minimal. Waste materials would be disposed of in accordance with established procedures, and would be well within the capacity of existing facilities. The probability of a transportation accident during shipment of depleted uranium oxide-containing modules between LANL and SNL would be small, and no adverse effects would be expected even if an accident were to occur. The Proposed Action will have little additional impact above and beyond the No Action Alternative. 


\section{TABLE OF CONTENTS}

Executive Summary $\ldots \ldots \ldots \ldots \ldots \ldots \ldots \ldots \ldots \ldots$ ES-i

List of Tables $\ldots \ldots \ldots \ldots \ldots \ldots \ldots \ldots \ldots \ldots \ldots \ldots$

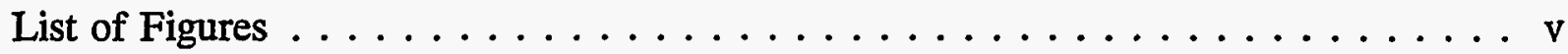

Abbreviations and Acronyms $\ldots \ldots \ldots \ldots \ldots \ldots \ldots \ldots$ vii

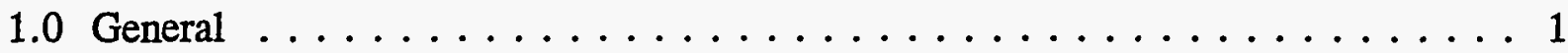

1.1 Background Information $\ldots \ldots \ldots \ldots \ldots \ldots \ldots \ldots \ldots$

1.2 Purpose and Need for Action $\ldots \ldots \ldots \ldots \ldots \ldots \ldots \ldots$

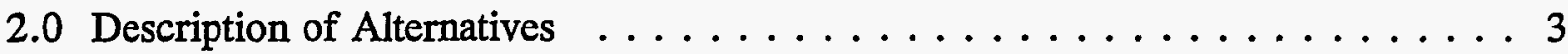

2.1 Proposed Action Alternative $\ldots \ldots \ldots \ldots \ldots \ldots \ldots \ldots \ldots$

2.1 .1 Connected Actions . . . . . . . . . . . . . . . 3

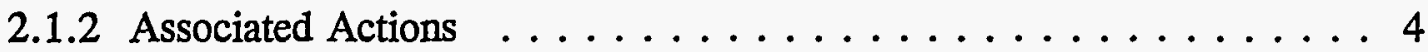

2.1.3 Description of SNL Sled Track Facility . . . . . . . . . 4

2.1.4 Description of Proposed Action Test Series . . . . . . . . . . 9

2.1.4.1 End-On RTG Impact Test Series . . . . . . . . . . . . . 15

2.1.4.2 Side-On GPHS/RTG Impact Test Series . . . . . . . . 15

2.1.5 Description of Proposed Action Test Procedures . . . . . . . . 16

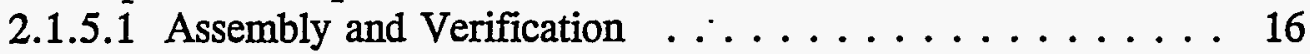

2.1.5.2 Post-test Recovery . . . . . . . . . . . . . . . 16

2.1.5.3 Analysis and Disposition of Test Materials . . . . . . . 17

2.1.6 Emissions and Wastes of the Proposed Action . . . . . . . 17

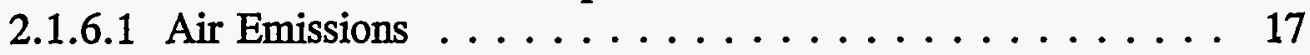

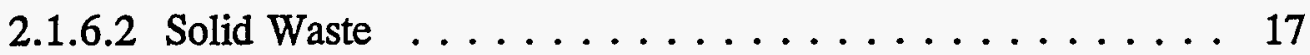

2.1.6.3 Hazardous Waste . . . . . . . . . . . . . 17

2.1.7 Transportation Issues of the Proposed Action . . . . . . . . 18

2.2 Alternatives to the Proposed Action $\ldots \ldots \ldots \ldots \ldots \ldots \ldots \ldots$

2.2 .1 No Action Alternative $\ldots \ldots \ldots \ldots \ldots \ldots \ldots \ldots \ldots$

2.2.2 Other Alternative Actions $\ldots \ldots \ldots \ldots \ldots \ldots \ldots \ldots$

2.2.2.1 Location of Tests at Sites Other than SNL . . . . . . . 18

2.2.2.2 Alternative Materials . . . . . . . . . . . . 19

3.0 Description of the Affected Environment $\ldots \ldots \ldots \ldots \ldots \ldots \ldots \ldots \ldots$

3.1 Regional Setting . . . . . . . . . . . . . . . 21

3.1.1 Land Use and Demography $\ldots \ldots \ldots \ldots \ldots \ldots \ldots \ldots \ldots$

3.1.2 Geology, Hydrology, and Climatology $\ldots \ldots \ldots \ldots \ldots \ldots 22$

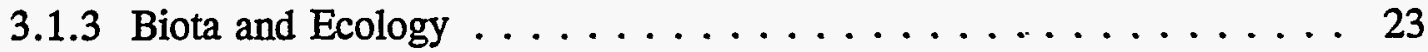

3.1 .4 Cultural Resources . . . . . . . . . . . . . . . . 25

3.1 .5 Native American Concerns . . . . . . . . . . . . 25 


\section{TABLE OF CONTENTS (Continued)}

3.2 Radiological Environment . . . . . . . . . . . . . . . 25

3.3 Noise Environment . . . . . . . . . . . . . . . . 26

3.4 Air Quality . . . . . . . . . . . . . . . . 27

3.5 Waste Disposal ....................... 27

4.0 Environmental Consequences . . . . . . . . . . . . . . . . 29

4.1 Normal Operations . . . . . . . . . . . . . . . . . . . . . . . . . 29

4.2 Radiological and Toxicological Effects of Uranium . . . . . . . . . 29

4.2 .1 Impacts of the Proposed Action . . . . . . . . . . . . . 29

4.2.2 Impacts of the No Action Alternative . . . . . . . . . . 30

4.3 Noise Impacts . . . . . . . . . . . . . . . . . 30

4.3.1 Impacts of the Proposed Action . . . . . . . . . . . . 30

4.3.1.1 Noise Levels from the Erection of Test Fixtures . . . . . . . 31

4.3.1.2 Noise Levels from Electrical Generators . . . . . . . . . 31

4.3.1.3 Noise from Rockets . . . . . . . . . . . . . . . 31

4.3.1.4 Noise from Collisions . . . . . . . . . . . . 32

4.3.2 Impacts of the No Action Alternative . . . . . . . . . 32

4.4 Air Quality Impacts . . . . . . . . . . . . . . . 32

4.4.1 Impacts of the Proposed Action . . . . . . . . . . . 33

4.4.1.1 Air Contaminant Amounts . . . . . . . . . . . . 33

4.4.1.2 Air Contaminant Concentrations . . . . . . . . . 33

4.4.2 Impacts of the No Action Alternative . . . . . . . . . 33

4.5 Waste Disposal . . . . . . . . . . . . . . . . . 33

4.5.1 Impacts of the Proposed Action . . . . . . . . . . . 33

4.5.2 Impacts of the No Action Alternative . . . . . . . . . . 34

4.6 Accident Scenarios . . . . . . . . . . . . . . . . . 34

4.6.1 Impacts of the Proposed Action . . . . . . . . . . . . 34

4.6.1.1 Dispersal of Depleted Uranium . . . . . . . . . . . 34

4.6.1.2 Methanol Spill . . . . . . . . . . . . . . . 34

4.6.1.3 Transport Between LANL and SNL . . . . . . . . 35

4.6.2 Impacts of the No Action Alternative . . . . . . . . . . . 35

5.0 Agencies and Persons Consulted $\ldots \ldots \ldots \ldots \ldots \ldots \ldots \ldots \ldots$

List of References . . . . . . . . . . . . . . . . . . . . . . 39

Appendix A-Potential Effects on Human Health and Safety $\ldots \ldots \ldots$ A-1

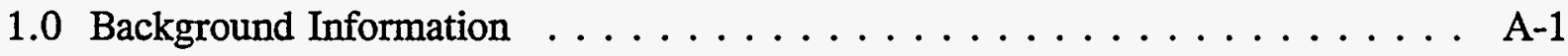

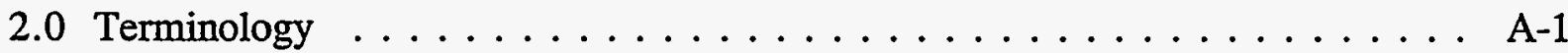

3.0 Definition of Ground Hazard Areas $\ldots \ldots \ldots \ldots \ldots \ldots$ A-2 


\section{TABLE OF CONTENTS (Continued)}

4.0 Depleted Uranium Background Information $\ldots \ldots \ldots \ldots \ldots \ldots$ A-2

5.0 Impacts from Depleted Uranium . . . . . . . . . . . . . . . A-4

5.1 Previous Site Evaluations . . . . . . . . . . . . . A-5

5.2 Evaluation of Potential Airborne Uranium Concentrations . . . . . . . A A-6

5.3 Evaluation of Chemical Toxicity $\ldots \ldots \ldots \ldots \ldots \ldots \ldots \ldots \ldots$

5.4 Evaluation of Radioactivity . . . . . . . . . . . . . A-7

5.5 Evaluation of an Accident Involving Release of Depleted Uranium Oxide . . A-9

5.6 Health Impacts for a Hypothetical Spill of Methanol . . . . . . . . . A-10

Appendix B-Air Quality Investigation $\ldots \ldots \ldots \ldots \ldots \ldots \ldots$ B-1

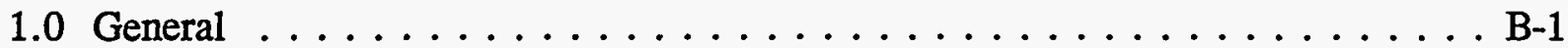

1.1 Air Contaminant Amounts $\ldots \ldots \ldots \ldots \ldots \ldots \ldots \ldots \ldots$ B-1

1.1.1 Rocket Motors . . . . . . . . . . . . . . . . . . B-1

1.1.2 Electrical Generators and Construction Equipment . . . . . . . . B-2

1.1.3 Summary of Air Contaminant Quantities . . . . . . . . . . . B-3

1.2 Air Contaminant Concentrations $\ldots \ldots \ldots \ldots \ldots \ldots \ldots \ldots$ B-4

1.2.1 Rocket Motors . . . . . . . . . . . . . . . . . B-4

1.2.2 Generators and Construction Equipment ... . . . . . . B-7 
TABLE OF CONTENTS (Continued)

This page intentionally left blank. 


\section{LIST OF TABLES}

Table

Page

Table 1. Summary of Test Series Configurations . . . . . . . . . . . . 10

Table A-1. Radiation Protection Standards-Limiting Values for Assessed Dose from Exposure of Occupational Workers and the General Public

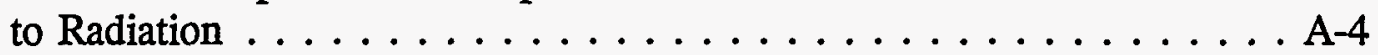

Table A-2. Soil Sample Summary . . . . . . . . . . . . . . . A-5

Table A-3. Projected Airborne Uranium Concentrations $\ldots \ldots \ldots \ldots \ldots$. . . . . 6

Table A-4. Time-Weighted Averages for Uranium Exposure . . . . . . . . . . . A-7

Table A-5. Potential Radiation Doses and Health Risks to Workers under the Proposed Action . . . . . . . . . . . . A-9

Table B-1. Characteristics of Mighty Mouse and HVAR Rocket Motors . . . . . . B B-2

Table B-2. Air Contaminants Released by Rocket Motors . . . . . . . . . . . B-2

Table B-3. Estimated Emissions of Air Contaminants from Generators and Construction Equipment . . . . . . . . . . B-3

Table B-4. Air Contaminant Emissions During Test by Contaminant and Source Category . . . . . . . . . . . . . . B-3

Table B-5. Initial Exhaust Plume Air Contaminant.Concentrations and TimeWeighted Average Exposure and Excursion Limits . . . . . . . . B-5

Table B-6. Estimated Concentrations at a Downwind Distance of $10 \mathrm{~m}$ from Generators and Construction Equipment . . . . . . . . B-7

\section{LIST OF FIGURES}

Figure

Page

Figure 1. Location of Sandia National Laboratory and Sled Track Test Facility . . . 5

Figure 2. Sled Track at Technical Area III . . . . . . . . . . . . 6

Figure 3. Typical Rocket-Propelled Sled . . . . . . . . . . . . 7

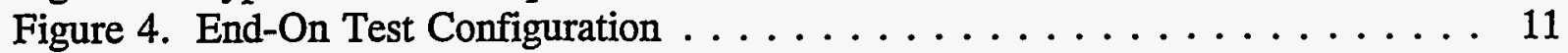

Figure 5. Side-On Test Configuration . . . . . . . . . . . . . . . 12

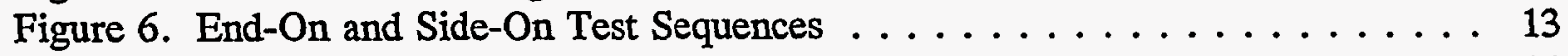

Figure 7. RTG Section with Numbered Modules . . . . . . . . . . 14 
This page intentionally left blank. 


\section{ABBREVIATIONS AND ACRONYMS}

${ }^{\circ} \mathrm{C}$

${ }^{\circ} \mathrm{F}$

$\mu \mathrm{Ci} / \mathrm{g}$

$\mathrm{ABC} / \mathrm{AQCB}$

ACGIH

AIA

Bldg.

CAS

CEQ

CFR

$\mathrm{cm}$

$\mathrm{dB}$

dBA

DOE

DOT

EA

EPA

ER

ES\&H Manual

fps

$\mathrm{ft}$

GHA

GPHS

$\mathrm{h}$

HVAR

in

KAFB

$\mathrm{kg}$

$\mathrm{km}$

$\mathrm{km}^{2}$

KSC

LANL

lb

LEL

$\mathrm{m}$

$\mathrm{m} / \mathrm{s}$

$\mathrm{mg} / \mathrm{m}^{3}$

$\mathrm{mi}$

$\mathrm{mi}^{2}$

$\mathrm{mm}$ degrees Celsius

degrees Fahrenheit

microcurie per gram

Albuquerque-Bernalillo County Air Quality Control Board

American Conference of Governmental Industrial Hygienists

Albuquerque International Airport

Building

Center for Anthropological Studies

Council on Environmental Quality

Code of Federal Regulations

centimeter(s)

decibel(s)

decibel(s) on the A-weighted scale

U.S. Department of Energy

U.S. Department of Transportation

Environmental Assessment

U.S. Environmental Protection Agency

Environmental Restoration

SNL Environment, Safety, and Health Manual

feet per second

foot or feet

Ground Hazard Area

General-Purpose Heat Source

hour(s)

High Velocity Aircraft Rocket

inch(es)

Kirtland Air Force Base

kilogram(s)

kilometer(s)

square kilometer(s)

Kennedy Space Center

Los Alamos National Laboratory

pound(s)

Lower Explosive Limit

meter(s)

meters per second

milligrams per cubic meter

mile(s)

square mile(s)

millimeter(s) 


\section{ABBREVIATIONS AND ACRONYMS (Continued)}

$\begin{array}{ll}\text { moly } & \text { molybdenum } \\ \text { MOU } & \text { Memorandum of Understandings } \\ \text { mph } & \text { miles per hour } \\ \text { mrem/yr } & \text { milliroentgen equivalent man per year } \\ \text { NASA } & \text { National Aeronautics and Space Administration } \\ \text { NEPA } & \text { The National Environmental Policy Act of 1969 } \\ \text { NRC } & \text { U.S. Nuclear Regulatory Commission } \\ \text { OSHA } & \text { U.S. Department of Labor Occupational Safety and } \\ & \text { Health Administration } \\ \text { pCi/g } & \text { picoCuries per gram } \\ \text { PEL } & \text { Permissible Exposure Limit } \\ \text { ppm } & \text { parts per million } \\ \text { rem } & \text { Roentgen equivalent man } \\ \text { RESRAD } & \text { Residual Radioactive Materials Guidelines } \\ \text { RMMA } & \text { Radioactive Material Management Area } \\ \text { RTG } & \text { Radioisotope Thermoelectric Generator } \\ \text { SMRU } & \text { Solid Motor Rocket Upgrades } \\ \text { SNL } & \text { Sandia National Laboratories } \\ \text { SOP } & \text { Standard Operating Procedures } \\ \text { STEL } & \text { Short-Term Exposure Limit } \\ \text { STS } & \text { Space Transportation System } \\ \text { TERA } & \text { Terminal Effects Research and Analysis } \\ \text { TLV } & \text { Threshold Limit Value } \\ \text { TWA } & \text { Time-Weighted Average }\end{array}$




\subsection{GENERAL}

This Environmental Assessment (EA) has been prepared to comply with the Council on Environmental Quality (CEQ) regulations implementing procedural provisions of The National Environmental Policy Act of 1969 (NEPA), as amended, and U.S. Department of Energy (DOE) regulations regarding NEPA found in the Code of Federal Regulations (CFR) under 40 CFR 1500-1508 and 10 CFR 1021, respectively. This EA presents the results of investigations conducted to determine if implementation of the Proposed Action or alternatives would or would not have the potential to cause a significant impact to the environment, or if an Environmental Impact Statement is necessary to further analyze potential impacts.

\subsection{BACKGROUND INFORMATION}

The mission of DOE is to carry out the Nation's policies regarding energy and defense programs in a safe and environmentally acceptable manner. In support of this mission, DOE has entered into Memoranda of Understandings (MOUs) with the National Aeronautics and Space Administration (NASA) to pursue research and development of space program energy sources and components. A recent MOU, dated July 26, 1991, concerns development and testing of the Radioisotope Thermoelectric Generator (RTG) (DOE, 1991a).

The General-Purpose Heat Source (GPHS) is a modular heat source fueled by plutonium-238 oxide (plutonium oxide) originally designed for use in RTGs installed in NASA Galileo and Ulysses spacecraft. These were launched successfully in 1989 and 1990. An RTG uses heat generated by alpha-decay of plutonium to create a temperature differential across a thermoelectric array to generate electrical power. This electrical power is used to operate spacecraft during long space missions. The fully configured GPHS/RTG would contain a total of 11 kilograms $(\mathrm{kg})$ (24 pounds [lb]) of plutonium oxide in 18 GPHS modules. Each GPHS module provides a reliable, long-term thermal output of 250 watts.

Galileo and Ulysses were both launched by the NASA Space Transportation System (STS) launch vehicle, commonly known as the Space Shuttle. Extensive testing was conducted on the GPHS/RTG to evaluate damaging effects of potential launch pad and near post launch explosions of the STS. The primary purpose of this testing was to provide data to assure that plutonium oxide-fueled GPHS/RTGs would survive these potential events without rupturing and releasing plutonium oxide.

Twenty-four space launches have involved RTGs. The importance of a comprehensive safety review is demonstrated by the fact that three of those launches involved accidents-Transit 5BN in 1964, Nimbus B1 in 1968, and Apollo 13 in 1970. In all three cases, the RTGs performed according to design requirements. In the first incident, an early generation RTG dispersed its plutonium oxide fuel at high altitude, as intended, after the satellite failed to achieve orbit. Subsequently, RTGs were redesigned to contain their fuel in all events. The Nimbus B1 event involved a mission abort, and the Apollo 13 event 
involved atmospheric reentry of a package designed to be left on the moon. Both RTGs successfully contained their nuclear fuel. Computer modeling and impact testing of simulated components provided crucial data for the flight safety review process.

Testing of GPHS/RTGs with simulated fuel for the STS missions was conducted by DOE at the Sandia National Laboratories (SNL) 10,000-Foot Sled Track Facility in 1987. Among other factors, this testing was conducted on the premise that the GPHS/RTG would be extensively safety qualified and the qualification would remain unchanged for future missions (George, 1987). At that time, it was concluded that future testing would be required to supply baseline safety information for RTG use under differing mission profiles, launch vehicles, and accident assumptions.

\subsection{PURPOSE AND NEED FOR ACTION}

DOE has determined that existing experimental data on GPHS/RTG performance under accident explosion and impact scenarios does not encompass the full range of combinations of mission profiles, launch vehicles, and accident assumptions. This existing data is inadequate to provide technically valid safety assessments for all RTG uses. A detailed safety assessment is required to support the flight safety certification process for any proposed RTG use. Based on potential launch and post-launch accidents, DOE has identified a need to test the GPHS/RTG to further quantify how well the assembly would limit release of radioactive material after end-on impacts and side-on impacts.

End-on impact tests would simulate the GPHS/RTG hitting the ground or another solid surface if the launch vehicle were destroyed near the launch pad. The side-on impact tests would simulate a launch explosion or other catastrophic event in which a piece of aluminum rocket skin or other debris would strike the GPHS/RTG at high velocity.

These additional tests would provide important baseline safety information that would support the flight safety certification process for future NASA outerplanetary space missions, including the Cassini mission to Saturn, scheduled for launch in 1997. 


\subsection{DESCRIPTION OF ALTERNATIVIES}

\subsection{PROPOSED ACTION ALTERNATIVE}

The Proposed Action would consist of using existing facilities in Technical Area III at SNL to conduct a series of physical impact tests on test articles (RTG sections containing a stack of GPHS modules) supplied by Los Alamos National Laboratory (LANL), with equipment supplied by both LANL and SNL. The individual test articles would consist of one half of an RTG section containing a stack of nine GPHS modules loaded with either nonradioactive molybdenum or low-level radioactive depleted uranium oxide pellets. These materials were chosen to simulate plutonium oxide used in RTGs during actual space missions. The tests would evaluate response of GPHS modules to conditions that might be experienced as a result of launch accidents. The Proposed Action test period is February through June 1995, and would involve a work force of about 15 people. Wastes and emissions generated as a result of the proposed impact tests at SNL either would be disposed of at SNL disposal facilities or released to the environment. At the conclusion of the physical impact tests, impact test data and the test articles and equipment supplied by LANL would be returned to LANL.

\subsubsection{Connected Actions}

Activities connected to the Proposed Action include the initial design, construction, and preliminary testing of various pieces of test equipment, together with the assembly of test articles at existing facilities in Technical Area 35 and Technical Area 55 at LANL, which is located in Los Alamos, New Mexico. This equipment, consisting of the test stand, lifting assembly, electric furnace, and expendable rocket sleds fitted for the RTG sections, and the test articles would be transported to SNL over a distance of approximately 163 kilometers (km) (101 miles [mi]).

After completion of the activities constituting the Proposed Action, the equipment and test articles supplied by LANL would be returned to LANL for evaluation at Technical Area 35 and Technical Area 55. Post-impact test articles would undergo further examination and studies. These would include photographing the test articles and making visual observations; aqueous sieving of the depleted uranium oxide to determine the particle size of the postimpact test article material; and metallurgical testing of the outer metal cladding that encased the depleted uranium oxide pellets. The depleted uranium oxide contained in the test articles would eventually be reprocessed by LANL, and the remaining equipment and material would be appropriately disposed of as either low-level radioactive waste or nonradioactive industrial waste at LANL disposal facilities. Wastes generated during the post-impact analysis, such as laboratory wipes and paper towels, would be disposed of in a similar manner.

These LANL activities constitute continuing activities for LANL. These types of activities supporting the space nuclear systems development and development of plutonium radioisotopic heat power sources were analyzed in the 1979 Final Environmental Impact 
Statement for LANL (DOE, 1979). Aqueous sieving of depleted uranium oxide samples was the subject of a 1993 DOE Environmental Checklist/Action Description Memorandum LAN 93-049 (DOE, 1993d); the action was determined to correspond to a categorical exclusion applicable to indoor bench-scale research projects and conventional laboratory operations. Further NEPA analysis for these actions is not required in this EA.

\subsubsection{Associated Actions}

SNL began performing qualification trials for GPHS testing at the existing SNL Sled Track in December 1994. Qualification trials consist of using simple mass simulants involving aluminum blocks and plates to demonstrate that rocket sled performance test parameters can be achieved. These qualification tests were the subject of a DOE Environmental Checklist/Action Description Memorandum, SNA-95-020 (DOE, 1994a). It was determined that the trials conformed to continuing activities at the Sled Track in Technical Area III that were analyzed in the 1977 Environmental Impact Statement for SNL (ERDA, 1977). Although this testing represents an activity associated with the Proposed Action, it can proceed independently of the Proposed Action; therefore, it is considered separately from actions analyzed in this EA.

\subsubsection{Description of SNL Sled Track Facility}

To better understand the Proposed Action, this section provides information on and a brief description of the existing facility proposed for use. Figure 1 shows the location of SNL and the 10,000-Foot Sled Track Facility near Albuquerque, New Mexico.

The SNL Sled Track is located in Technical Area III on the DOE portion of 9,233 hectares $(24,500$ acres) managed by DOE and the U.S. Air Force. Figure 2 shows the location of the Sled Track in Technical Area III and its geographical relationship to other nearby test facilities. The Sled Track consists of a twin rail, 10,000-foot-long track similar to a railroad, except the track is a heavier gauge rail constructed on a continuous concrete abutment, and the rail separation is only 66 centimeters $(\mathrm{cm})$ (26 inches [in]) center to center. Test articles are carried on sleds which are designed to slide on metal runners mated to the rails. The sleds are pushed by various types of surplus military rocket motors to velocities ranging from about 30 meters per second $(\mathrm{m} / \mathrm{s})$ (100 feet per second [fps]) up to $2,000 \mathrm{~m} / \mathrm{s}(6,500 \mathrm{fps})$ (SNL, 1994).

During a typical year, about 50 tests are conducted at the Sled Track involving firing about 350 rocket motors. Figure 3 is a photograph of a typical rocket-propelled sled. This photograph shows a test article on a sled propelled by a cluster of rocket motors. 


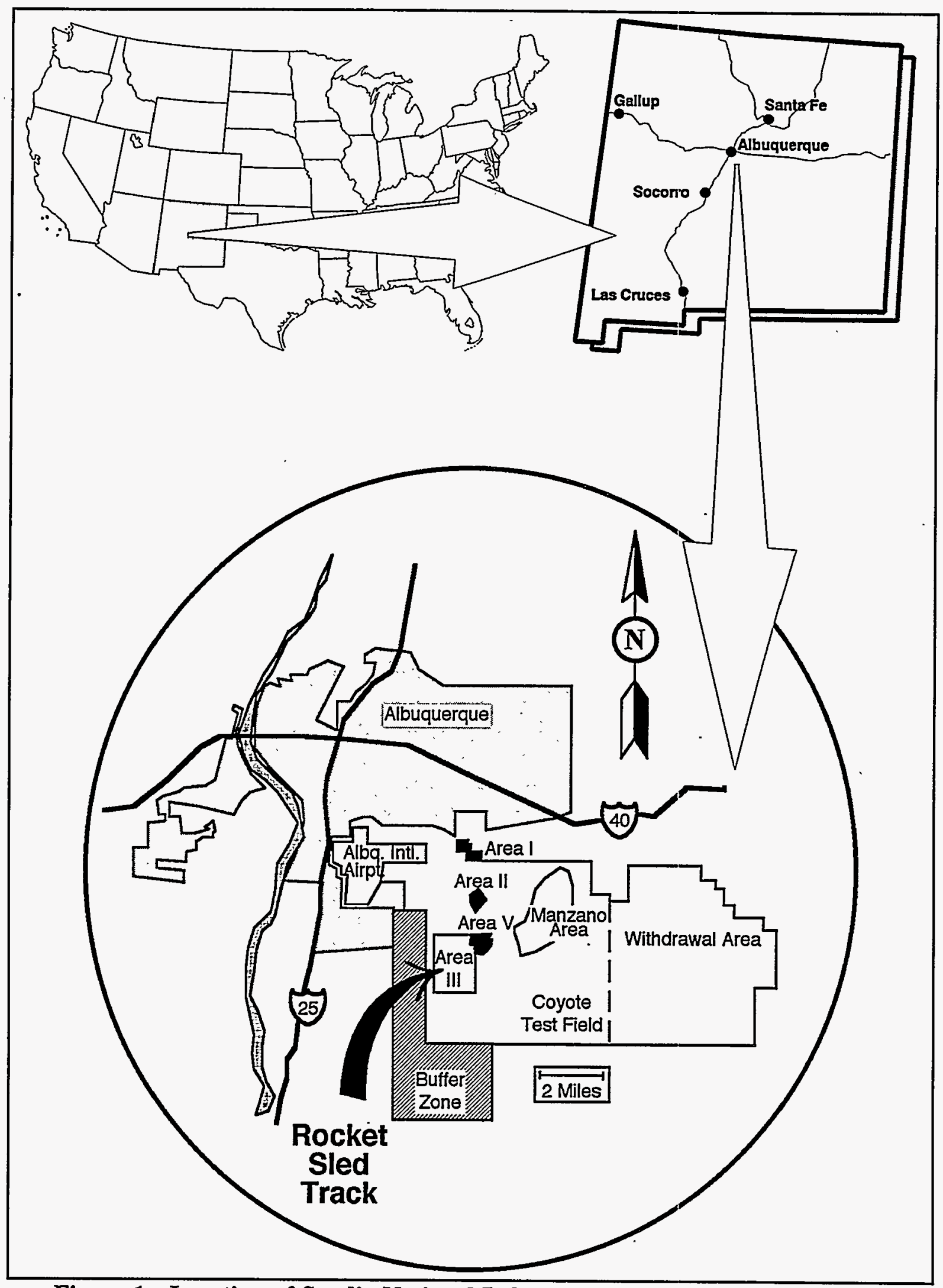

Figure 1. Location of Sandia National Laboratories and Sled Track Facility 


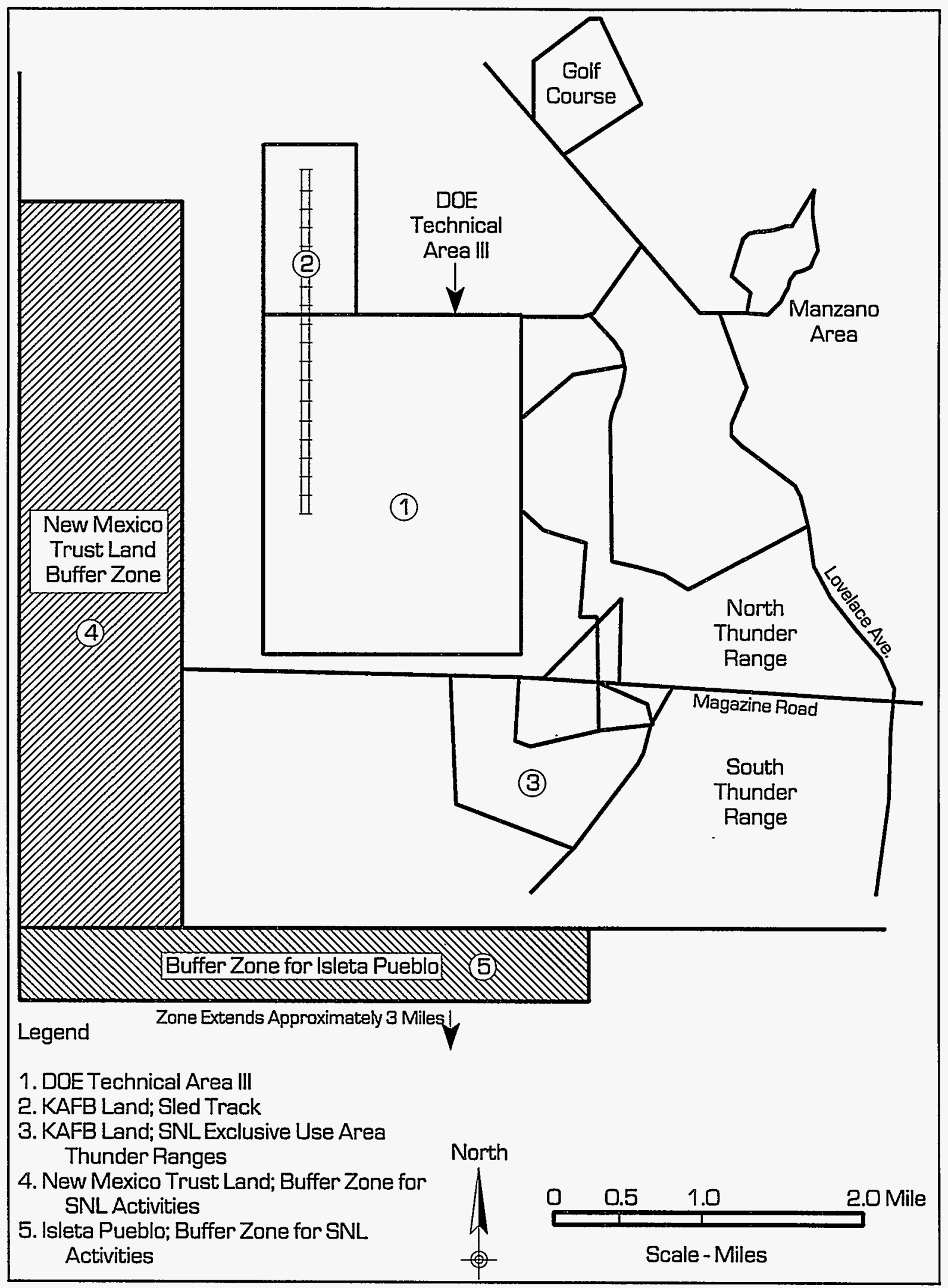

Figure 2. Sled Track at Technical Area III 


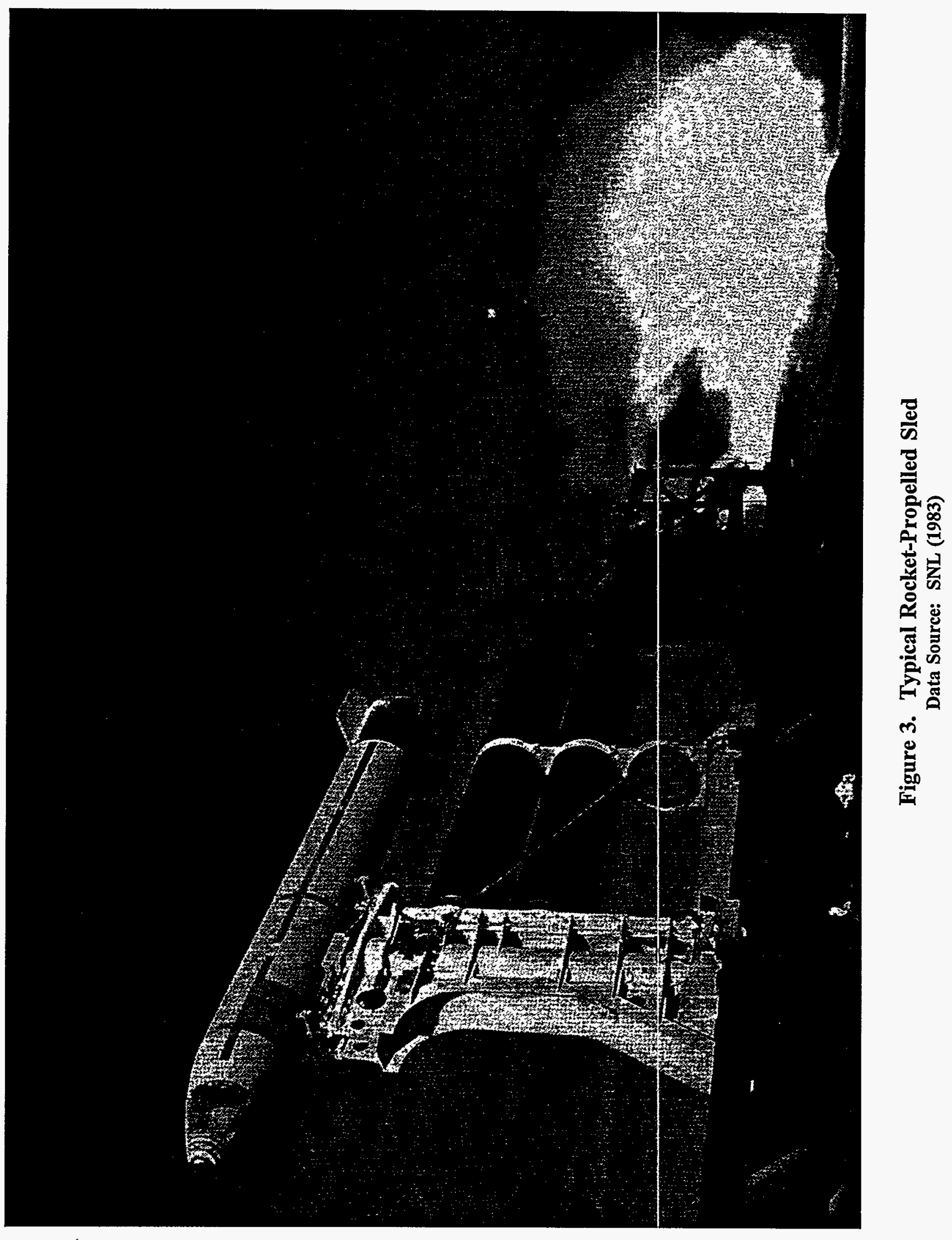


The function of the track is to conduct the following types of tests:

- Collision-impact tests by accelerating the test article to impact a fixed target

- Reverse-impact tests in which the target is accelerated into the test article

- Parachute deployment tests

- Dynamic weapon firing tests

- Full function weapon deployment tests

- Sensor and telemetry system verification

- Rocket sled development

Sleds with attached test articles or targets are propelled from north to south starting at a launch point calculated to provide the terminal velocity required for the specific test. At a precalculated point near the south end of the track, test articles collide against fixed targets, accelerated targets collide with fixed test articles, or test articles are ejected into a free-flight trajectory impacting with targets at predetermined distances. The rocket sled is stopped by a barrier such as an earthen berm or steel barricade located at the end of the track, or by a water braking system that allows the sled to be brought to a controlled, nondestructive stop. Following each test, any visible debris is collected, inspected for possible radiation contamination, and removed by SNL personnel for evaluation and appropriate disposal.

Sled Track facilities that would be used in the Proposed Action include the following buildings and structures.

Control Building, Workshop and High-Bay Assembly Area (Building 6741 [Bldg. 6741]): This building would be the central control point for conducting tests. The Workshop and High-Bay area would be used to assemble the sled and payload components except for the rocket motors.

Rocket Motor Conditioning Facility (Bldg. 6743): This facility is certified for conditioning solid rocket motors. Motors would be thermally stabilized at constant temperature before a test to assure consistent performance. Motors would be attached to the sled in this building.

Instrumentation Bunker (Bldg. 6742): This is an underground bunker that houses instrumentation equipment used to record the test data.

Rocket Motor Storage Magazine (Bldg. 6747): This is a small earth-bermed building used to store rocket motors.

The Sled Track Facility is designated as Environmental Restoration (ER) Site No. 83 and contains Radioactive Material Management Area (RMMA) Location No. 308. The ER designation primarily was based on lead deposition from rocket motor exhaust gases. The RMMA designation was based on the existence of depleted uranium fragments and residue from previous test programs. For the proposed test series, the test stand assembly would be placed near an area known to contain depleted uranium from previous tests. In addition, 
previous reports mention widely dispersed slivers of rocket propellant along the length of the track.

\subsubsection{Description of Proposed Action Test Series}

The Proposed Action is to perform testing to provide data needed for safety verification of the GPHS/RTG. The testing would evaluate capability of the GPHS/RTG to prevent rupture and release of radioactive material caused by the force of impact at postulated launch accident velocities. Test data would be derived from two test series at the SNL Sled Track Facility: the End-On Test Series and the Side-On Test Series. The test article would be one half of an RTG filled with a stack of nine GPHS modules. To duplicate actual GPHS/RTG operating temperatures, GPHS module stacks would be heated using an electric-powered furnace to 1,097 degrees Celsius $\left({ }^{\circ} \mathrm{C}\right)\left(2,007\right.$ degrees Fahrenheit $\left.\left[{ }^{\circ} \mathrm{F}\right]\right)$, then inserted into the RTG sections. For each test series, plutonium oxide required for the actual planetary missions would be simulated by use of depleted uranium oxide. This material closely matches plutonium oxide in terms of density and thermal and mechanical characteristics.

The overall test series would consist of sequential engineering and test-article tests. Engineering tests would serve as a "dress rehearsal" for operation of the GPHS/RTG, furnace assembly, release mechanisms, and target alignment. These tests also would provide concept verification of all impact scenarios. Nonradioactive material (molybdenum) would be used for engineering tests, followed by tests using depleted uranium oxide. These tests would be similar to the engineering tests, except that depleted uranium oxide would be used in selected modules instead of molybdenum.

To provide an accurate simulation of actual launch configurations, GPHS modules containing depleted uranium oxide would be made of a slightly different carbon-composite material than the GPHS modules containing molybdenum. Additionally, capsules containing depleted uranium oxide would be clad in iridium to simulate the protection given to plutonium oxide modules.

To meet the needs of the rigorous flight safety certification analyses, the GPHS/RTG would be varied for different test configurations. There would be minor variations in the number of modules containing depleted uranium oxide, and in the type of graphite aeroshell casing and iridium cladding for different test configurations (DOE, 1994b). From the perspective of potential environmental consequences, the number of modules that would contain depleted uranium oxide is of greatest importance. A total of $7.2 \mathrm{~kg}(15.9 \mathrm{lb})$ of depleted uranium oxide would be subjected to potential rupturing caused by high-impact forces. As a result of computer modeling and previous impact testing, test planners do not expect GPHS/RTG assemblies to release any materials during the proposed tests.

Table 1 contains a summary of specific details for each test series. Following this table, details are provided for each of the specific tests. 
Table 1. Summary of Test Series Configurations

\begin{tabular}{ccccc}
\hline Test Series & $\begin{array}{c}\text { Number of } \\
\text { Sled Runs }\end{array}$ & $\begin{array}{c}\text { Test } \\
\text { Purpose }\end{array}$ & $\begin{array}{c}\text { GPHS Module } \\
\text { Contents/Test }\end{array}$ & $\begin{array}{c}\text { Number/Type of } \\
\text { Motors/Test }\end{array}$ \\
\hline $\begin{array}{c}\text { End-On: } \\
\text { Impact Velocity } \\
56 \mathrm{~m} / \mathrm{s}\end{array}$ & 2 & Engineering & $5.4 \mathrm{~kg}$ Moly & 2 Mighty Mouse \\
& 1 & Test Article & $\begin{array}{l}3.0 \mathrm{~kg} \mathrm{DUO} \\
2.4 \mathrm{~kg} \mathrm{Moly}\end{array}$ & 2 Mighty Mouse \\
\hline $\begin{array}{c}\text { End-On: } \\
\text { Impact Velocity }\end{array}$ & 2 & Engineering & $5.4 \mathrm{~kg} \mathrm{Moly}$ & 3 Mighty Mouse \\
75 to $91 \mathrm{~m} / \mathrm{s}$ & 1 & Test Article & $\begin{array}{l}3.6 \mathrm{~kg} \mathrm{DUO} \\
1.8 \mathrm{~kg} \mathrm{Moly}\end{array}$ & 3 Mighty Mouse \\
\hline $\begin{array}{c}\text { Side-On: } \\
\text { Impact Velocity }\end{array}$ & 2 & Engineering & $1.8 \mathrm{~kg} \mathrm{Moly}$ & $20 \mathrm{HVAR}{ }^{2}$ \\
$305 \mathrm{~m} / \mathrm{s}$ & 1 & Test Article & $\begin{array}{l}0.6 \mathrm{~kg} \mathrm{DUO} \\
1.2 \mathrm{~kg} \mathrm{Moly}\end{array}$ & $20 \mathrm{HVAR}$ \\
\hline
\end{tabular}

$1 \quad \mathrm{DUO}_{2}=$ depleted uranium oxide; Moly $=$ Molybdenum

2 HVAR $=$ High Velocity Aircraft Rocket

Most equipment used during testing would be furnished by LANL. Material provided by LANL would include RTG sections and GPHS modules containing molybdenum and depleted uranium oxide, the test stand, lifting assembly, electric furnace, and expendable rocket sleds for the End-On test series fitted for the RTG sections. SNL would furnish the test facility, rocket motors, and reusable sleds for the Side-On test series and the calibration runs.

The test stand would consist of a simple elevated platform, an electric furnace, and a lifting assembly to load heated GPHS modules into RTG sections. It would be designed, constructed, and tested at LANL to assure the furnace and lifting mechanism operate correctly. At SNL, the test stand would be placed to straddle the Sled Track, and final assembly of the furnace and the lifting mechanism to the test stand would take place. No excavation or construction work would be necessary to position the test stand. The entire stand would be transported in a preassembled form so that it could be lifted into place by a small crane. The approximate exterior dimensions of the stand would be 3.0 meters (m) $(10$ feet $[\mathrm{ft}])$ wide, $4.3 \mathrm{~m}(14 \mathrm{ft})$ long, and $3.7 \mathrm{~m}(12 \mathrm{ft})$ in height.

Figures 4 and 5 show the End-On and Side-On test configurations. Figure 6 is an artist's conception of the different test sequences. Figure 7 is an artist's conception of the GPHS/RTG. 


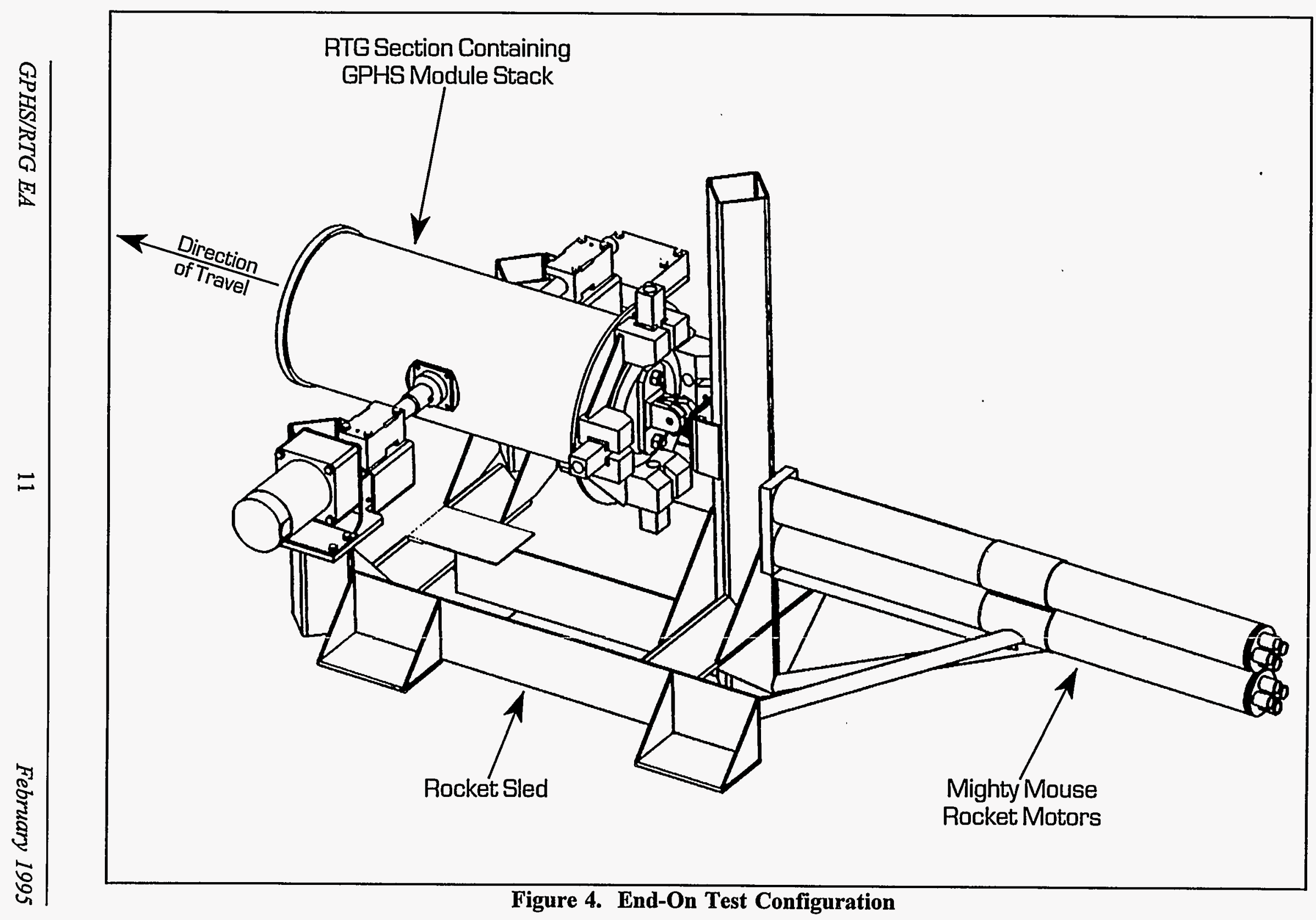




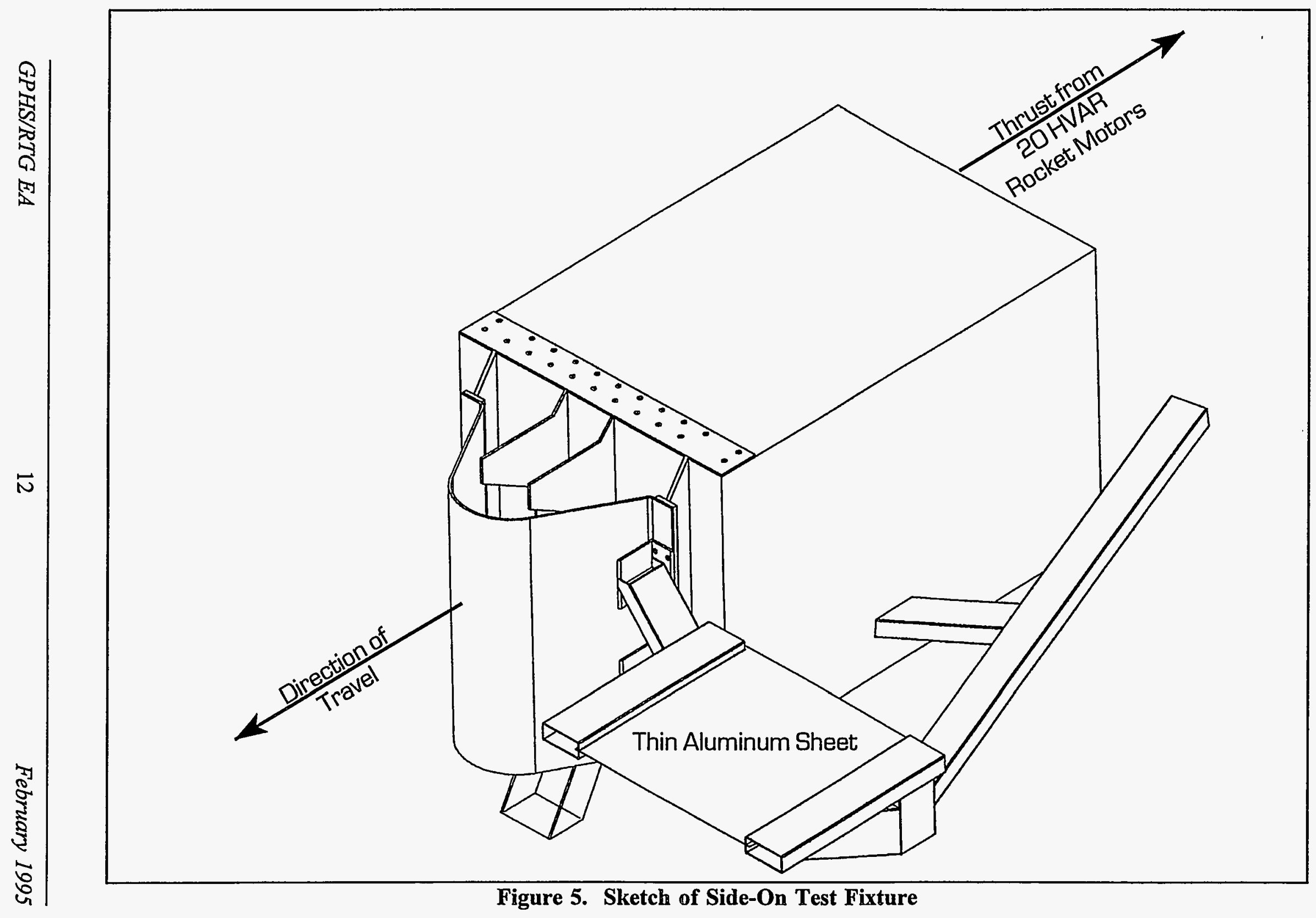




\section{End-on Test Series}

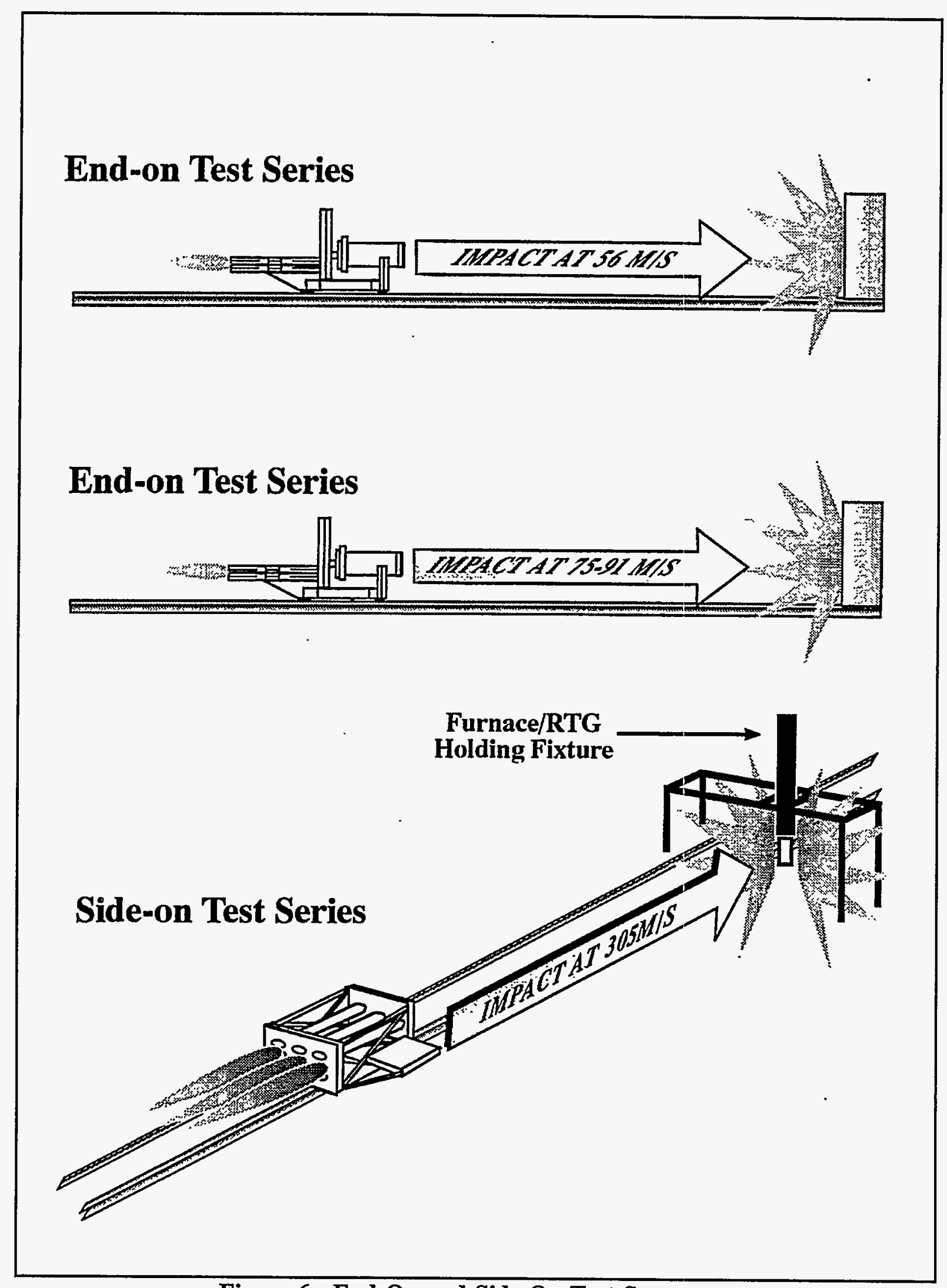

Figure 6. End-On and Side-On Test Sequences 


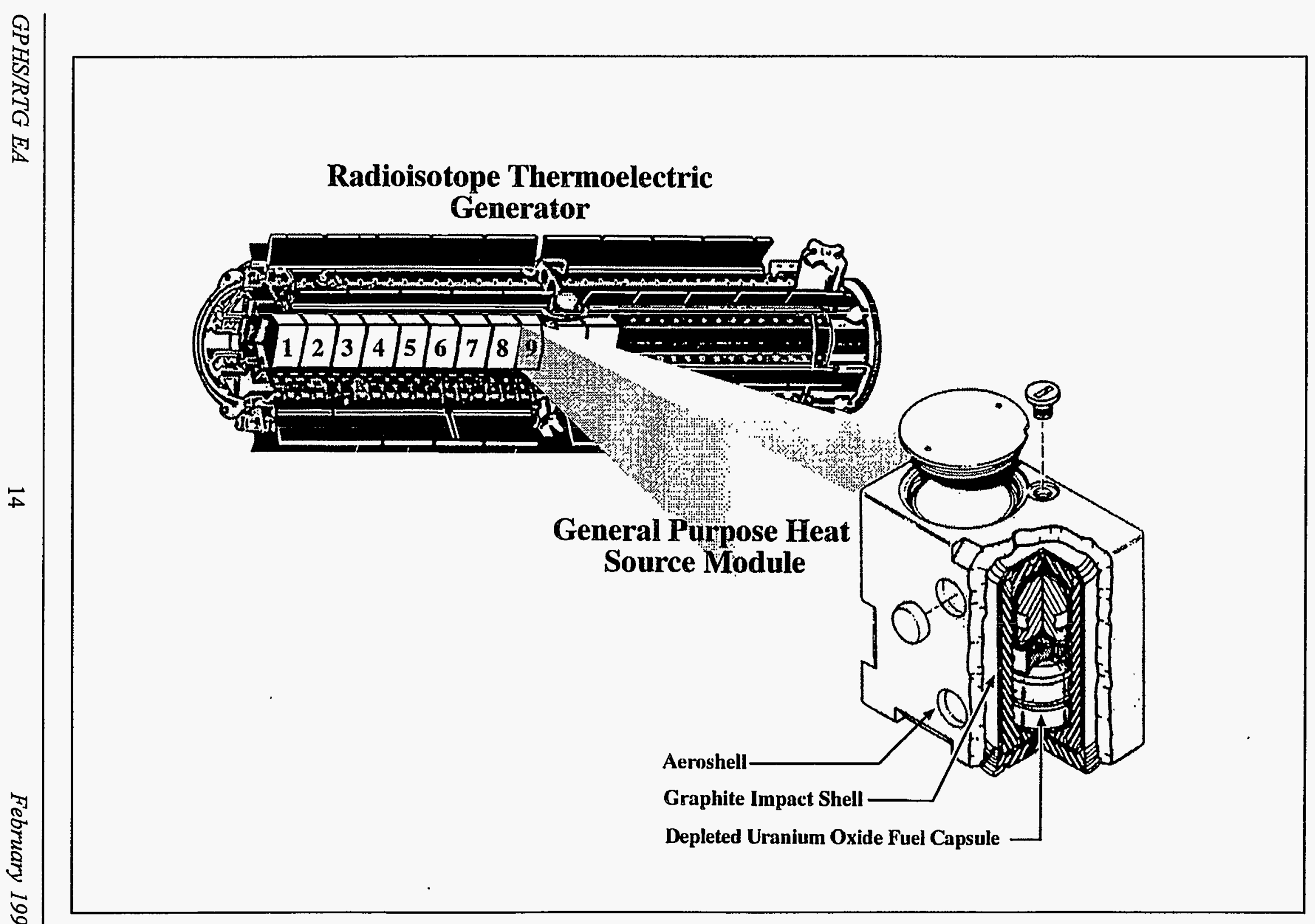

Figure 7. RTG Section with Numbered Modules Data Source: Cull, 1989 


\subsubsection{End-On RTG Impact Test Series}

For the End-On test series, the target would be a concrete slab. The GPHS module numbers shown in Figure 7 are used to define the locations that would be occupied by fuel capsules. Each GPHS/RTG would be placed in a horizontal position on the sled. Position 1 is the impact end of the GPHS/RTG. The sled would be stopped by impact into a steel barrier, but the GPHS/RTG would fly freely through an aperture in the sled barrier before striking the concrete target placed a short distance behind the aperture. The concrete target is approximately $1 \mathrm{~m} \times 1.2 \mathrm{~m} \times 0.45 \mathrm{~m}$ (36 in $\times 48$ in $\times 18$ in). The concrete target would be provided by the NASA Kennedy Space Center (KSC) and is of the composition and construction type typical of the KSC Launch Complex in Florida. At impact, the GPHS/RTG would be stopped and fall on the ground between the barrier and concrete target within a few feet of the impact point.

End-On tests would be conducted at two impact velocities. In the first configuration, the rocket sled and GPHS/RTG would be propelled by two rocket motors (Mighty Mouse) to impact at $56 \mathrm{~m} / \mathrm{s}$ (185 fps). In the second configuration, three Mighty Mouse motors would be used to propel the sled and GPHS/RTG to impact between $75 \mathrm{~m} / \mathrm{s}$ (246 fps) and $91 \mathrm{~m} / \mathrm{s}$ (299 fps). The concrete target would be placed at the extreme southern end of the track. The rocket sled would be launched approximately $60 \mathrm{~m}(197 \mathrm{ft})$ to the north.

The End-On Tests have two scenarios involving depleted uranium oxide. In the first scenario, the RTG section would contain five GPHS modules loaded with a total of $3.0 \mathrm{~kg}$ $(6.6 \mathrm{lb})$ of depleted uranium oxide and four modules loaded with a total of $2.4 \mathrm{~kg}(5.3 \mathrm{lb})$ of molybdenum. In the second scenario, the RTG section would contain six GPHS modules loaded with a total of $3.6 \mathrm{~kg}(7.9 \mathrm{lb})$ of depleted uranium oxide and three modules loaded with a total of $1.8 \mathrm{~kg}(4 \mathrm{lb})$ of molybdenum.

The terminal test fixtures include a metal barrier and the concrete target. The metal barrier would be supported by wooden posts and steel cable guy-wires. A packed soil embankment on three sides of the concrete target would act as a backstop to hold the target in place. Some repair and modification of these fixtures likely would be required and the target would be replaced after each test. A total of up to 15 Mighty Mouse motors would be used during the End-On tests. Each Mighty Mouse motor contains $2.7 \mathrm{~kg}(6.0 \mathrm{lb})$ of double-base solid propellant. Motors containing solid propellant are insensitive to physical shock such as being dropped, although they can ignite if involved in a fire or subjected to electrical discharge. Remote handling devices are not necessary for safe handling.

\subsubsection{Side-On GPHS/RTG Impact Test Series}

For the Side-On test series, one half of an RTG would contain only three GPHS modules and the remaining space in the module stack would be occupied by a carbon-composite block spacer. An GPHS/RTG would be a stationary target suspended in a vertical position by the test stand. It would be struck side-on by a thin aluminum sheet 1.6 millimeters $(\mathrm{mm})$ $(0.062 \mathrm{in})$ thick, and approximately $0.6 \mathrm{~m}(2 \mathrm{ft})$ square mounted on a rocket sled. 
All Side-On tests would be conducted at a single impact velocity (which could be up to $305 \mathrm{~m} / \mathrm{s}$ [1,000 fps]). The rocket sled would be propelled by up to 20 High Velocity Aircraft Rocket (HVAR) motors, which also use solid propellant. These tests would use a larger portion of the track. The rocket sled would be launched about $1,065-1,140 \mathrm{~m}$ (3,493-3,740 ft) from the extreme southern end of the Sled Track. After carrying the thin aluminum sheet to the impact point located about $150 \mathrm{~m}(500 \mathrm{ft})$ down range from the launch point, the sled would coast for a short distance and then be slowed to a stop by a water braking system. About $400 \mathrm{~m}$ (1,300 ft) of the track would be used for the Side-On test.

The RTG section for the Side-On engineering test would contain 3 GPHS modules with $1.8 \mathrm{~kg}(4.0 \mathrm{lb})$ of molybdenum. The RTG section for the Side-On Test-Article test would contain one GPHS module with $0.6 \mathrm{~kg}(1.3 \mathrm{lb})$ of depleted uranium oxide and two GPHS modules with molybdenum (total of $1.2 \mathrm{~kg}$ [2.6 lb] molybdenum). A total of up to 60 HVAR motors would be expected to be used during the Side-On tests. Each HVAR motor contains $10.9 \mathrm{~kg}(24 \mathrm{lb})$ of double-base solid propellant.

\subsubsection{Description of Proposed Action Test Procedures}

The following is a brief description of the process that would be followed for equipment assembly and verification, post-test recovery, and analysis and disposition of test materials.

\subsubsection{Assembly and Verification}

After assembly of test equipment is completed, final connections would be made to the electrical power sources from the Control Room (Bldg. 6741) and the Instrumentation Bunker (Bldg. 6743). Existing commercial electrical power or a diesel-powered electric generator would be used by the furnace at the test stand to heat the GPHS modules.

The test stand would be positioned to straddle the track so that rocket sleds could pass beneath the elevated platform. The test stand would be aligned with the track so that the GPHS module stack could be lowered directly from the furnace into the RTG section on the sled for End-On tests. For Side-On tests, the test stand would serve as a fixture aligning the GPHS/RTG in a vertical position just above the track.

\subsubsection{Post-test Recovery}

After a test, the temperature of the GPHS/RTG would still be very hot, near $1,000^{\circ} \mathrm{C}$ $\left(1,832^{\circ} \mathrm{F}\right)$. Standard Operating Procedures (SOP) for post-test recovery would be established to power-down equipment and to assure the impact area is safe for personnel. Safety procedures would include waiting for rocket exhaust gases to dissipate and checking the solid rocket motors for unburned propellant. These procedures also would allow the test articles time to cool before attempting recovery, preparing for the next test, or disassembling for return shipment to LANL. 


\subsubsection{Analysis and Disposition of Test Materials}

Equipment and materials will be examined to meet requirements for removal from the Sled Track RMMA area. LANL-furnished equipment and materials would be returned to LANL for further analysis and final disposition. Materials would undergo a radiological examination and decontamination if necessary at SNL before materials are repackaged for their return shipment to LANL. After additional analysis has been completed at LANL, the entire quantity of depleted uranium oxide would be returned to the LANL special materials inventory. Other items would be disposed of as either low-level radioactive waste or as solid waste. Low-level radioactive waste would be disposed at LANL Technical Area 54 Lowlevel Radioactive Waste Facilities. Solid waste such as $265 \mathrm{~kg}(595 \mathrm{lb})$ of steel from the damaged rocket sleds would either be reclaimed and recycled, or disposed of at the Los Alamos County landfill (or its replacement equivalent).

\subsubsection{Emissions and Wastes of the Proposed Action}

Emissions and wastes from these proposed test series at SNL are listed in the following subsections. Most of the solid wastes would either be recycled or disposed of in a sanitary landfill. Some widely dispersed fragments of wood or concrete may not be recoverable after testing. Hazardous wastes would be segregated and stored temporarily at a designated waste accumulation area for removal by SNL Hazardous Waste Management Organization. These materials will be handled in accordance with SNL Waste Management Procedures (SNL, 1992a).

\subsubsection{Air Emissions}

Sixty HVAR motors will produce carbon monoxide, lead, sulfur dioxide, and potassium hydroxide. Fifteen Mighty Mouse motors will produce carbon monoxide and lead. Total emissions are $366 \mathrm{~kg}(807 \mathrm{lb})$.

\subsubsection{Solid Waste}

Solid waste would consist of approximately

- 20 wóoden posts, 4" $\times 4^{\prime \prime}$

- $265 \mathrm{~kg}(585 \mathrm{lb})$ of steèl scrap from sleds

- $15 \mathrm{~kg}(33.1 \mathrm{lb})$ of concrete pieces

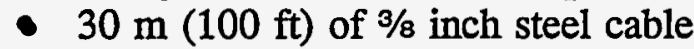

- 60 HVAR steel motor cases $(1,579 \mathrm{~kg}[3,480 \mathrm{lb}])$

- 15 Mighty Mouse aluminum motor cases (37.4 kg [82.5 lb])

\subsubsection{Hazardous Waste}

Hazardous waste would consist of approximately

- $0.45 \mathrm{~kg}(1 \mathrm{lb})$ of unburned rocket propellant

- $4.5 \mathrm{~kg}(10 \mathrm{lb})$ of hazardous chemical waste including solvent- and lubricantcontaminated rags 


\subsubsection{Transportation Issues of the Proposed Action}

RTG sections and GPHS modules would be transported between LANL and SNL, a distance of $163 \mathrm{~km}(101 \mathrm{mi})$. These items would be transported in accordance with U.S. Department of Transportation (DOT) regulations for transporting radioactive materials (49 CFR 173).

Transportation of rocket motors within SNL to storage locations at the Sled Track Facility would be handled by the SNL Explosive Storage Team. This organization handles the receipt, storage, transportation, and disposal of rocket motors at SNL using DOE-approved procedures and equipment. Rocket motors would be delivered to the Sled Track Rocket Storage Magazine (Bldg. 6747).

\subsection{ALTERNATIVES TO THE PROPOSED ACTION}

\subsubsection{No Action Alternative}

The No Action Alternative is defined as the case in which no testing of the GPHS would be conducted. Data from previous impact tests were used to establish safety verification of the RTG for STS launch vehicles. Under the No Action Alternative, safety verification of the GPHS/RTG for alternate launch configurations would have to be accomplished without the benefit of impact test data from the proposed test series. Future safety reviews would rely solely on modeling and data from previous STS test results. Furthermore, the baseline safety database would not be updated or expanded with new experimental data that could benefit the launch safety review process for all future missions. This alternative would not meet DOE's purpose and need for action. It will be analyzed in this EA to provide a baseline for the Proposed Action.

\subsubsection{Other Alternative Actions}

\subsubsection{Location of Tests at Sites Other than SNL}

There are several alternative sled track facilities that potentially could conduct these tests. These locations are (1) the LANL PIXI Sled Track, Los Alamos, New Mexico; (2) Holloman Air Force Base Sled Track, Alamogordo, New Mexico; and (3) Terminal Effects Research and Analysis (TERA) Sled Track at New Mexico Institute of Mining and Technology, Socorro, New Mexico.

The alternative locations were dismissed from further consideration in this EA because of the following constraints:

(1) Although LANL has tested items containing depleted uranium oxide in the past, their facility was dismissed from consideration because its Sled Track is too short to meet the minimum impact velocities for Side-On tests. This track is roughly $1,000 \mathrm{ft}$ long, and a minimum length of about $1,500 \mathrm{ft}$ would be required using 
rocket propulsion to attain the required impact velocities and nondestructively decelerate the rocket sled.

In addition, the LANL Sled Track is a monorail design, which could allow the GPHS/RTG to strike the sled-arresting barrier instead of the target during End-On tests. If this were to occur, the GPHS/RTG could be destroyed without any useful data being collected; this is an important test constraint because the GPHS/RTG assemblies are valued at $\$ 1$ million each and there are no spares available. Engineering modifications of the LANL Sled Track are possible, but this would take considerable time and investment. This alternative would not offer significant environmental advantages over the proposed action.

(2) The facilities at Holloman Air Force Base and New Mexico Institute of Mining and Technology were dismissed from consideration because testing of items containing depleted uranium oxide currently is not allowed at these facilities. Renegotiation of this policy prohibiting testing using depleted uranium oxide could take considerable time. This alternative would not offer significant environmental advantages over the proposed action.

\subsubsection{Alternative Materials}

Hafnium oxide could be used to simulate plutonium oxide for the entire test series in place of depleted uranium oxide. However, an extensive database exists to allow test data on depleted uranium oxide to be used to simulate plutonium oxide. Hafnium oxide has a different density, strength characteristics, and thermal properties than depleted uranium oxide. Using it as a substitute for depleted uranium oxide was rejected on the basis that no database exists to make valid comparisons between damage to this material and plutonium oxide. 
This page intentionally left blank. 


\subsection{DESCRIPTION OF THE AFFECTED ENVIRONMENT}

A comprehensive description of the SNL site and the affected environment is presented in the site-wide Environmental Impact Assessment of SNL (ERDA, 1977) with updated information contained in the annual Environmental Baseline Update report (SNL, 1992b). A summary of relevant information is presented in the following paragraphs.

\subsection{REGIONAL SETTING}

\subsubsection{Land Use and Demography}

SNL is located in Bernalillo County, in central New Mexico, adjacent to the City of Albuquerque. At their nearest points, SNL facilities are $4 \mathrm{~km}(2.5 \mathrm{mi})$ south of Interstate 40 and approximately $10.5 \mathrm{~km}(6.5 \mathrm{mi})$ east of downtown Albuquerque. The facilities are surrounded by Kirtland Air Force Base (KAFB), with SNL Exclusive Use Areas and co-use agreements on some U.S. Air Force property. Areas to the west and south of SNL/KAFB are bounded by land managed by the State of New Mexico and Isleta Pueblo (Figure 2), Albuquerque lies to the north and the Cibola National Forest and the Manzanita Mountains are located to the east. Albuquerque is the largest population center in Bernalillo County and also is the closest population center to SNL. The 1990 U.S. Census shows an Albuquerque population of 384,736 . The Isleta Indian Pueblo, which borders KAFB on the south, is the next nearest population center with a 1990 census of 2,915. An estimated total population of 578,313 people live within a $80-\mathrm{km}(50-\mathrm{mi})$ radius of SNL, including on-base residents of KAFB (DOC, 1991).

SNL consists of five technical areas and several remote test areas situated in the eastern half of the 19,000-hectares (46,900-acre) KAFB military reservation. The Sled Track is located in SNL Technical Area III, comprising approximately 777 hectares (1,920 acres) and Sled Track permanent facilities occupy 30 hectares $(75$ acres). Approximate distances from the southern end of the Sled Track where testing is proposed to KAFB entrance gates at Wyoming and Gibson Boulevards are $9.2 \mathrm{~km}(5.6 \mathrm{mi})$ and $8.5 \mathrm{~km}(5.2 \mathrm{mi})$, respectively. Distance to the Veteran's Hospital along Gibson Boulevard is approximately $8.6 \mathrm{~km}$ $(5.3 \mathrm{mi})$. The Isleta Pueblo is approximately $14.3 \mathrm{~km}(8.9 \mathrm{mi})$ southwest, and the Pueblo land boundary is $4 \mathrm{~km}(2.5 \mathrm{mi})$ south of the Sled Track. The nearest on-base residential housing (Zia Park Housing) is located approximately $5.5 \mathrm{~km}(3.4 \mathrm{mi})$ northwest of the site. The nearest off-base residential housing in the City of Albuquerque is located approximately $7.3 \mathrm{~km}(4.6 \mathrm{mi})$ northeast of the site. The Sled Track is about $1.5 \mathrm{~km}(1 \mathrm{mi})$ from the western or nearest boundary of KAFB (SNL, 1994).

The land area occupied or influenced by the Sled Track Facilities and activities is governed by five land use agreements. These agreements include DOE-managed land inside Technical Area III and Exclusive Use Areas established for SNL activities on KAFB land. Also applicable are agreements covering safety exclusion zones outside Technical Area III on KAFB land, and outside KAFB boundaries on land owned by the State of New Mexico 
and Isleta Pueblo (Permit Numbers DACA47-4-84-25 and DE-ACO4-79-AL11282; Lease Number 420318 8994). Applicable provisions of SNL's Environment, Safety, and Health Manual, MN47001 (ES\&H Manual) (SNL, 1991) establish safety exclusion zones within Technical Area III for Sled Track activities. Largest of these safety exclusion zones is the 18-degree zone, centered on the Sled Track, and extending $4 \mathrm{~km}(2.5 \mathrm{mi})$ south of Technical Area III to the KAFB/Isleta Pueblo boundary. The safety exclusion zones are buffers for the physical protection for members of the general public. None of the land at or immediately adjacent to the Sled Track is used for agricultural purposes.

\subsubsection{Geology, Hydrology, and Climatology}

SNL is located at the base of and in the foothills of the Manzanita Mountains. The general area is a high, arid plateau rising toward the mountains to the east and sloping gently down to the Rio Grande to the west. To the northeast lies Tijeras Canyon, which divides the Sandia Mountains to the north from the Manzanita Mountains further south. Running west from the mountains, the canyon becomes an arroyo (a generally dry water course or wash) that trends through the eastern part of KAFB. The mean surface elevation of SNL/KAFB is $1,629 \mathrm{~m}(5,345 \mathrm{ft})$.

Surface geology of the Sled Track area includes several types of sedimentary deposits which have been eroded through natural processes so that different formations are exposed. Within the boundary of Technical Area III, sedimentary deposits include various types of gravel and wind-deposited sand.

The Albuquerque area is classified in the Uniform Building Code (I.C.B.O., 1988) as lying in Seismic Risk Zone 2, which is a zone subject to moderate seismic damage, and corresponds to intensity VII of the Modified Mercalli Scale, or an acceleration of about onetenth of the acceleration due to gravity. Moderate damage is a reasonable expectation, but of rare incidence. Earthquakes are also measured using the Richter Scale. The largest shock to be expected in New Mexico in a 100-year period is of Richter Scale magnitude 6 (Sanford, et al., 1972).

Although a magnitude 6 earthquake is the largest that can be expected, recent earthquake history shows a pattern of frequent, but much lower magnitude earthquakes. Since 29 November 1989, there have been four earthquakes in the same area near Socorro exceeding Richter Scale magnitude 4.0-one of 4.7 on 29 November 1989, one of 4.6 on 29 January 1990, one of 4.1 on 1 February 1990, and one of 4.3 on 8 November 1990.

Faults separate the regional water table into a somewhat deep region west of the fault complex and a much shallower region on the east. The depth to saturated ground water underlying SNL facilities varies from 15 to $30 \mathrm{~m}$ ( 50 to $98 \mathrm{ft}$ ) east of the faults and from 115 to $150 \mathrm{~m}$ ( 377 to $492 \mathrm{ft}$ ) west of the faults. Most SNL facilities are located west of the fault system in the area of deeper ground water. The land area evaluated in this EA for the Sled Track is underlain by the deeper ground water systems. The direction of ground water flow 
typically would be out of the canyons and westward toward the Rio Grande Valley and perpendicular to the fault system.

The major surface water feature in central New Mexico is the Rio Grande, which flows north-to-south through Albuquerque and lies $8 \mathrm{~km}(3.6 \mathrm{mi})$ west of SNL. Rio Grande water is primarily used for irrigation of agricultural crops. There are no continuously running streams on SNL property, although there are two perennial springs (Coyote and Sol se Mete) on KAFB. The two primary surface channels at SNL are Tijeras Arroyo and the smaller Arroyo del Coyote; both flow intermittently during heavy thundershowers. Tijeras Arroyo (above the confluence with Arroyo del Coyote) drains 114 square kilometers $\left(\mathrm{km}^{2}\right)$ (44 square miles $\left[\mathrm{mi}^{2}\right]$ ), while Arroyo del Coyote (above the confluence with Tijeras Arroyo) drains $39 \mathrm{~km}^{2}\left(15 \mathrm{mi}^{2}\right)$. Since SNL facilities are built above the flood plain of these surface features, flooding is an unlikely event.

The climate is mild and dry, but given to large diurnal and seasonal variations in temperature, from a record high of $41^{\circ} \mathrm{C}$ to a record low of $-27^{\circ} \mathrm{C}\left(105^{\circ} \mathrm{F}\right.$ to $\left.-17^{\circ} \mathrm{F}\right)$. Official records are taken at Albuquerque International Airport and are indicative of Sled Track conditions. Mountainous topography also channels surface winds into Tijeras Canyon, resulting in occasional periods of high winds of up to $31 \mathrm{~m} / \mathrm{s}$ (70 miles per hour [mph]) in portions of SNL. Clear, sunny days with light to moderate winds predominate. Rain, principally in July through September, is characterized by brief, violent thunderstorms with high rainfall. Winds during the dry spring months produce dust storms. Easterly winds are the most common.

An average of 41 thunderstorm days per year occur in the Albuquerque area. The majority of these thunderstorm days occur during the rainy summer period. About $20 \mathrm{~cm}(8 \mathrm{in})$ of rainfall occurs per year. An average of six days per year have fog (visibility less than $0.4 \mathrm{~km}$ [0.25 mi]). Although tornadoes are virtually nonexistent in the Albuquerque area, small tornadoes were reported in 1985 and 1987. Damage was very light and no official wind readings were recorded. Based on climatological records, Albuquerque is classified as a region of low-tornado occurrence, with an estimated frequency of less than one tornado every ten years.

\subsubsection{Biota and Ecology}

The area is categorized as desert grassland habitat and is associated with foothills of the adjacent Manzanita Mountains. Vegetation consists of sage, cactus, and associated grassland habitat, grading into juniper, piñon, and ponderosa pine at higher elevations. Information in the following paragraphs summarize the results of biological field investigations of the area containing the Sled Track and is extracted from a biological assessment completed in 1992 and 1993 by Sullivan and Knight (1994). This report contains a detailed description of the biological survey.

The impact zone at the southern end of the Sled Track has been used extensively by many test programs for over 20 years. As a result, the land in the impact zone has been heavily 
disturbed and transformed from its natural state. The Proposed Action would include a relatively small number of tests, and the radius of disturbance would be relatively small. None of the actions of the proposed tests would extend into undisturbed areas.

Of the total of 1,520 hectares (3,760 acres) surveyed by Sullivan and Knight (1994), the Sled Track facilities and test area comprised about 624 hectares (1,542 acres). A primary objective of the biological survey of the area potentially affected by Sled Track activities was to identify the presence of any plant or animal species of special concern with regard to status of legal protection. The survey covered 100 percent of the Sled Track Safety Exclusion Zone and the areas in the immediate vicinity of each Sled Track facility. This biological survey found several species present in the vicinity of some of the Sled Track facilities and the Sled Track Safety Exclusion Zone that were either threatened, endangered or protected under State and Federal laws and regulations. There are no populations of domestic or feral horses, burros, or cattle.

The biological survey revealed the presence grama grass cactus (Toumeya papyracantha [Engel.] Britt \& Rose) that is a Federal Category 2 candidate species (under the Endangered Species Act), and also is designated as a New Mexico Endangered Species. As evaluated by Sullivan and Knight (1994), the nearest individual specimen of grama grass cactus is located more than $305 \mathrm{~m}(1,000 \mathrm{ft})$ away from the portion of the Sled Track at which the proposed testing would occur. No individual specimens of grama grass cactus would directly or indirectly be affected by the proposed testing.

Seven animal species (swamp rattlesnake [Sistrurus catenasus], short-horned lizard [Phrynosoma douglassi], round-tailed horned lizard [Phrynosoma modestum], Texas horned lizard [Phrynosoma cornutum], American Kestrel [Falco sparverius], Loggerhead Shrike [Lanius ludovicianus], and Burrowing Owl [Athene cunicularia]) were found. Of these species, the Loggerhead Shrike and the Texas horned lizard are of special concern under both Federal and State designation (Federal Category 2 candidate species and State of New Mexico Protected Species). The Texas horned lizard is rare in the area, but the Loggerhead Shrike was observed to be plentiful, and 31 individuals were noted in the vicinity of Technical Area III facilities. Because of the limited duration and extent of intense noise, and the limited radius of activities associated with the proposed testing, wildlife would not be adversely affected.

Five of the animal species observed during the biological surveys are defined as New Mexico Protected Species. These species were the Massasagua swamp rattlesnake, the short-horned lizard, the round-tailed horned lizard, the American Kestrel, and the Burrowing Owl. The biological surveys found that less than 2.7 percent of the habitat area showed evidence of disturbance, and previous testing had caused no significant habitat disruption or transformation. It is noted that all of these animal species are mobile, and those individual specimens that were found were widely dispersed. 


\subsubsection{Cultural Resources}

No historic or prehistoric sites were found in the Sled Track Area likely to be affected by the Sled Track testing activities; additionally, there should be none-to-minimal impact to historic or prehistoric resources located nearby. Areas surveyed in both the 1990 and 1992 surveys previously were inventoried for cultural resources during three separate projects conducted by the Center for Anthropological Studies (CAS) between 1979 and 1981. These prior surveys inventoried all of the KAFB land surrounding Technical Area III. These three CAS surveys were reported to be intensive, with crew spacing at 15-meter (49 ft) intervals for gently sloping terrain and with crew spacing adjusted according to the terrain on steeper slopes. The CAS team collected all isolated occurrences that were located.

A cultural resources inventory was completed for approximately 374 hectares (925 acres) at KAFB (Hoagland, 1992). Areas investigated are located on the western piedmont of the Manzano and Manzanita Mountains east of Albuquerque, New Mexico. The survey area included the Sled Track extension north of Technical Area III and three sample transects located within the Sled Track Safety Exclusion Zone.

Technical Area III at SNL also was surveyed in 1990 in an area encompassing the east portions of Sections 19 and 30 and almost all of Sections 20 and 29. In total, the survey area covered 765 hectares $(1,890$ acres) (Hoagland, 1990). That survey yielded no significant cultural resources.

One cultural resource site (LA 89044) and 10 isolated occurrences were located during the 1992 archaeological survey. The cultural resource site and five isolated occurrences were documented to be well outside the area occupied by the Sled Track. Four isolated occurrences were found in the Sled Track Safety Exclusion Zone and one isolated occurrence was found in the Rocket Sled Track extension area.

\subsubsection{Native American Concerns}

The boundary of Isleta Pueblo is approximately $4 \mathrm{~km}(2.5 \mathrm{mi})$ south of the end of the Sled Track. DOE has negotiated a land-use agreement with Isleta Pueblo that provides a buffer zone with the Pueblo to accommodate infrequent operations that might affect Pueblo lands (DOE, 1990). The effects of the Proposed Action would not extend to the Isleta Pueblo boundary.

\subsection{RADIOLOGICAL ENVIRONMENT}

Radioactive materials associated with testing at the Sled Track have historically included depleted uranium and depleted uranium oxide, uranium alloys, thorium alloys and compounds, and tritium. The health of personnel working in this area could be impacted by the level of radioactive material present in the soil in the southern portion of the Sled Track. 
Fissionable materials such as plutonium-239 are not used in Sled Track testing activities. Radioactive materials used in most tests are in sealed assemblies when delivered to the Sled Track. Except for some weapon projectiles, these sealed assemblies are not opened before or after testing at the Sled Track Facility. These testing programs have been responsible for scattering depleted uranium fragments in the impact zone of the Sled Track. The most common material currently tested is depleted uranium, which is less radioactive than naturally-occurring uranium. In the past, test assemblies often contained depleted uranium to simulate the weight, mass properties, and other physical characteristics of fissionable and other radioactive materials. The Sled Track is designated as RMMA No. 308.

\subsection{NOISE ENVIRONMENT}

Background noise in the vicinity of the SNL Sled Track is dominated by the noise from civil and military aircraft approaching or departing Albuquerque International Airport (AIA). A survey of baseline noise levels was conducted in 1992 (SNL, 1992b) for SNL/KAFB. The next most important noise source was found to be motor vehicles. Survey results indicate that the maximum hourly average noise levels coincided with periods of peak airport operations, and noise levels at different locations at SNL correlated directly with proximity to aircraft approach and departure patterns.

Most of the noise monitoring at SNL has been done at Technical Area II where the average noise level has been measured at 54 decibels on the A-weighted scale (dBA) with peak values as high as $94 \mathrm{dBA}$ (SNL, 1992b). The A-weighted scale is used to measure human sound perception. Technical Area II is much closer to aircraft approach and departure patterns of AIA than is Technical Area III containing the Sled Track; therefore, the average value at the Sled Track likely would be lower. Computer models indicate that Technical Area III is well outside the $65 \mathrm{dBA}$ contour for the day-night average.

The nearest residential areas to Technical Area III fall within the 65 to $75 \mathrm{dBA}$ contours for the day-night average. Analysis indicates an average aircraft noise level in the range of 64-68 dBA would be expected during the work day. The day-night average, including the $10 \mathrm{dBA}$ penalty for nighttime noise, would be expected to be 68-70 dBA.

Vehicular traffic noise was estimated to be an average day-night noise level of $66 \mathrm{dBA}$ within Technical Area III at a distance of $30 \mathrm{~m}$ (100 ft) from the main access road. Because each 10 -fold increase in distance from a line source decreases the sound level by $15 \mathrm{dBA}$, the average vehicular noise level at the Sled Track would be expected to be negligible compared with aircraft noise.

In addition, other sources of noise contribute to the background level at the Sled Track. Generators occasionally are used at several sites within Technical Area III. Using the typical noise level of $76 \mathrm{dBA}$ at $15.2 \mathrm{~m}(50 \mathrm{ft})$, generator noise is negligible compared with aircraft and vehicles at distances greater than $120 \mathrm{~m}(400 \mathrm{ft})$ away. Rocket motors, guns, and explosives are used at several nearby test facilities. These sources produce sound of short duration and make a small contribution to the noise background. 


\subsection{AIR QUALITY}

Very little air quality baseline information is available for the Sled Track; with the exception of certain hazardous emissions, levels of common air contaminants are not monitored. Sufficient information to establish an air quality baseline was not available at this writing.

Air quality in Bernalillo County is regulated by the Albuquerque-Bernalillo County Air Quality Control Board (ABC/AQCB). Bernalillo County is currently in noncompliance with the regulation for ambient carbon monoxide concentration. The area is in compliance with Federal and New Mexico Ambient Air Quality Standards for other contaminants. The $\mathrm{ABC} / \mathrm{AQCB}$ conducts routine monitoring at several sites throughout the county, but none are close enough to the Sled Track to provide a meaningful characterization of the atmosphere at this site.

Most of the carbon monoxide in Bernalillo County originates within the City of Albuquerque, but the prevailing winds generally carry pollutants away from the Sled Track Facility. Much of the time, it is likely that the conditions at the Sled Track are similar to those in the surrounding semi-rural areas of the county rather than to those in Albuquerque. Because of the large tracts of sparsely vegetated land to the west of the test site, the particulate content from dust undoubtedly increases during periods of strong westerly winds.

\subsection{WASTE DISPOSAL}

Operations and tests at the Sled Track Facility generate solid waste and small quantities of hazardous waste such as solvent-soaked rags, residue from adhesives, spent aerosol containers, and waste solvents and lubricants. These wastes are handled in accordance with DOE Orders 5480.3 and 5820.2A, Environmental Protection Agency (EPA) 40 CFR regulations, and the procedures in Chapter 12, Onsite Transportation of Hazardous Materials and Wastes, from the ES\&H Manual. In addition, the SNL Hazardous Waste Management Organization regularly reviews the waste handling procedures and the designated waste accumulation areas at SNL. The SNL waste management organizations and personnel are capable of managing the quantity and types of waste generated at SNL using current procedures. Quantities of hazardous waste at SNL regulated under the Resource Conservation and Recovery Act (RCRA) average about 150,000 kg (34 tons) per year (SNL, 1993). 
This page intentionally left blank. 


\subsection{ENVIRONMENTAL CONSEQUENCES}

This section examines potential consequences to the existing environment associated with the Proposed Action and the No Action Alternative. In general, the amount of detail presented with respect to the various environmental categories in this section is proportional to the potential for adverse impacts.

Measures incorporated in activity-specific SOPs and routinely taken to mitigate possible adverse impacts are incorporated in the following. Subsections. For those mitigation measures required to reduce potential impacts to an inconsequential level, an analysis and discussion are provided for each appropriate environmental category.

The environmental components listed below are not discussed further in this EA.

- Geology and hydrology

- Biological resources

- Cultural resources

- Native American concerns

Issues discussed in this chapter are limited to those which may actually be affected by the Proposed Action.

\subsection{NORMAL OPERATIONS}

Approximately 50 Sled Track tests are conducted during a normal year. These result in the firing of approximately 350 rocket motors. The Proposed Action would involve nine Sled Track tests, and approximately 75 rocket motors would be fired. The Proposed Action represents less than 20 percent of the normal annual level of test activities. Except for the presence of depleted uranium oxide in some of the GPHS/RTG assemblies, the Proposed Action is no different than normal testing operations.

All operations would be governed by stringent requirements to protect the environment, the health and safety of the public, of personnel present at the Sled Track facility but not involved with the proposed test program, and of personnel directly involved with the test program. SNL ES\&H Manual (SNL, 1991) establishes policies, requirements, and standards for protecting environment, safety, and health based on DOE directives. The Sled Track Facility SOP sets specific test-related requirements. These documents and other DOE directives would be observed in the proposed test program.

\subsection{RADIOLOGICAL AND TOXICOLOGICAL EFFECTS OF URANIUM}

\subsubsection{Impacts of the Proposed Action}

Depleted uranium is a radioactive, toxic, and carcinogenic chemical. Personnel working in the historically contaminated area of the Sled Track would be exposed primarily through two 
mechanisms, contact with contaminated soil and through inhalation or ingestion of contaminated dust. Test preparations that might lead to exposure would consist of vehicular movement on unpaved areas, removing test debris, and erecting the metal sled barrier and concrete target at the end of the track. The potential health impacts to personnel are based on the level of residual depleted uranium in the soil and estimated airborne dust levels. Based on the evaluation presented in Appendix A, Subsection 5.4, the radiological exposure to personnel involved in the Proposed Action would not exceed a dose of 20 milliroentgen equivalent man (mrem). Based on a work force of 15 people, the cumulative worker dose would not exceed 0.25 person-rem. Using a dose-to-risk conversion factor of $4 \times 10^{-4}$ latent cancer fatalities per person-rem, the additional risk of cancer to the project personnel as the result of this program would be one in 10,000 . Another way to state this risk estimate is that one additional fatal cancer would be expected for every 10,000 programs of this magnitude.

Potential health effects from depleted uranium compounds also can arise from chemical toxicity. As evaluated in Appendix A, Subsection 5.3, a useful comparison between airborne uranium particulates that could be generated by winds and vehicles shows that potential exposure to depleted uranium would be a factor of 500 less than the Occupational Safety and Health Administration (OSHA) and American Conference of Governmental Industrial Hygienists (ACGIH) health standards, 200 micrograms per cubic meter $\left(\mu \mathrm{g} / \mathrm{m}^{3}\right)$.

\subsubsection{Impacts of the No Action Alternative}

Under the No Action Alternative, the potential exposure to residual depleted uranium in the soil as a result of the proposed test operations would not occur.

\subsection{NOISE IMPACTS}

Sources of noise during tests would arise from rocket motor firings, and sound generated by impacts with target surfaces. Noise exposure to operating personnel would be reduced by distance, protective gear, or protective structures. Noise from the Proposed Action could have three types of environmental effects: disturbance of residential and commercial settings, damage to worker hearing, and wildlife disturbance.

Functional activities considered in the assessments of noise effects are as follows:

- Minor construction

- Rocket motor firings

- Collision impacts

\subsubsection{Impacts of the Proposed Action}

Vehicle noise would occur whether or not the Proposed Action takes place and will not be analyzed in detail. Noise from generators and construction equipment would be negligible beyond the immediate vicinity of the roads and equipment. Ground Hazard Areas (GHA) for noise exposure from rockets and collisions would be smaller than the $381 \mathrm{~m}(1,250 \mathrm{ft}) \mathrm{GHA}$ 
established by the Sled Track SOP for protection from mechanical hazards. At the Sled Track Control Building (Bldg. 6741), maximum noise levels from rocket motors and collisions would be 107 and 95 decibels $(\mathrm{dB})$ respectively. These sound levels are measured with the unweighted $d B$ scale rather than the $A$-weighted scale (dBA) because it is a better way to characterize human perception of this type of sound. At the Gibson Boulevard entrance, transient noise levels from rocket motors and target impacts would be less than 95 and $83 \mathrm{~dB}$ respectively. Because of their short duration, these levels would make a contribution of less than $0.05 \mathrm{~dB}$ to the day-night average background noise level. This analysis was performed for the Gibson Boulevard entrance because prevailing wind conditions during the proposed test period likely would result in higher sound levels there than at other locations outside the SNL/KAFB complex. Noise effects of the Proposed Action are similar to those from operations during the 20 year history of the Sled Track. It is unlikely that wildlife will be adversely disturbed by the Proposed Action.

\subsubsection{Noise Levels from the Erection of Test Fixtures}

Noise levels caused by construction equipment can range from 76 to $91 \mathrm{dBA}$ at a distance

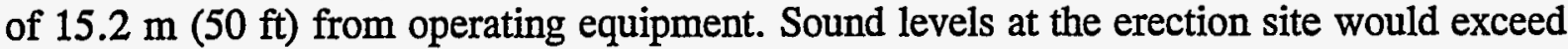
SNL guidelines for occupational sound exposure. Therefore, the construction workers would use hearing protection devices. Sound levels at nearby facilities, located greater than $25 \mathrm{~m}$ $(82 \mathrm{ft})$ from the operating equipment, however, would be considerably below ACGIH standards, and hearing protection would not be necessary.

\subsubsection{Noise Levels from Electrical Generators}

During site operations, electrical generators could be used. The noise level at $15.2 \mathrm{~m}$ from a diesel-powered generator is estimated to be typically $78 \mathrm{dBA}$ (Miller, 1980). The noise level from a diesel generator would decrease to $80 \mathrm{dBA}$ at a distance of $12 \mathrm{~m}$ (39 ft). Personnel continually exposed to $80 \mathrm{dBA}$ or greater would be required to be enrolled in the SNL Hearing Conservation Program. It is unlikely personnel working outside the immediate vicinity of the generator would be exposed to noise above this level. Given the short duration of the proposed test program, no employee hearing damage is expected to result from test activities associated with the use of electrical generators.

\subsubsection{Noise from Rockets}

All of the proposed tests would involve firing either Mighty Mouse or HVAR rocket motors. For the time period that rockets fire, noise exposure to personnel can reach $127 \mathrm{~dB}$ before the ACGIH noise standard is exceeded (ACGIH, 1993). Distances from the Sled Track have been calculated at which sound levels decrease to $127 \mathrm{~dB}$. These distances are $144 \mathrm{~m}(472 \mathrm{ft}$ ) and $25.5 \mathrm{~m}(84 \mathrm{ft}$ ) respectively for a cluster of 20 HVARs or 3 Mighty Mouse motors.

The methodology used to compute these values produces conservative estimates and therefore provides a margin of safety. All sled runs would be subsonic and would not produce sonic booms. These distances are less than the GHA radius of $381 \mathrm{~m}(1,250 \mathrm{ft})$ established for 
tests involving rocket motors. Since personnel are required to remain outside the GHA, they would not be exposed to injurious noise levels from rocket firings. At the Sled Track Control Building (Bldg. 6741), the noise level would be reduced to approximately $107 \mathrm{~dB}$. At the Gibson Boulevard entrance to SNL/KAFB, the noise level would be reduced to $95 \mathrm{~dB}$; although this would be above the background noise level, it probably would not be noticed because of its short duration.

\subsubsection{Noise from Collisions}

Proposed activities would result in noise from collisions between test articles and targets. Only a fraction of the energy from the collision would be dissipated acoustically. Most of the energy would be dissipated through mechanical deformation of the test article or target, heating or melting of the article, and conduction or dissipation through the earth. Noise levels from collisions were estimated by using a pile driver to compare energy dissipation during a sled impact. The result is a conservative estimate of a $130 \mathrm{~dB}$ sound level at a distance of $25 \mathrm{~m}(82 \mathrm{ft})$ from the impact point.

Because collisions would result in an impulsive sound, the level would be well within the ACGIH limits of $140 \mathrm{~dB}$ for impulsive sound. Moreover, the GHA radius for impact tests would be set at $412 \mathrm{~m}(1,350 \mathrm{ft})$ from the impact point. Since personnel would be required to remain outside the GHA, they would not be exposed to injurious noise levels. At the Sled Track Control Building (Bldg. 6741), the level would be approximately $95 \mathrm{~dB}$. At the Gibson Boulevard entrance, it would be approximately $83 \mathrm{~dB}$.

\subsubsection{Impacts of the No Action Alternative}

Under the No Action Alternative, the tests described in the Proposed Action would not take place. Impacts from noise would not occur.

\subsection{AIR QUALITY IMPACTS}

The primary air quality effect would be the release of the rocket exhaust products into the atmosphere. Space heating, vehicles, construction equipment, and electric generators also would release small amounts of air contaminants. Because buildings would be heated whether or not the RTG testing was conducted, emissions by space heating equipment would be the same for either the Proposed Action of the No Action Alternative. These emission rates were not included in the analysis.

The air emissions from 75 rocket motors fired during the Proposed Action would result in an increase over ambient concentrations of less than one-tenth of one percent $(0.1 \%)$ of the Federal and New Mexico Ambient Air Quality Standards (NM, 1992) at the Gibson Boulevard entrance. This location was analyzed because prevailing winds during proposed test period are more likely to transport contaminants in that direction than toward any other nearby area outside the SNL/KAFB complex, including the Isleta Pueblo. 


\subsubsection{Impacts of the Proposed Action}

\subsubsection{Air Contaminant Amounts}

Amounts of pollutants that would be emitted were estimated from the known properties of rocket motors, from EPA emission factors (EPA, 1985), and from estimates of generator usage. Emissions would include carbon monoxide, lead, sulfur dioxide, and potassium hydroxide. Detailed emission information is given in Appendix B, Subsection 1.1. Total quantities of air contaminants released are a fraction of regulatory limits including the pending General Conformity Regulation of the $A B C / A Q C B$ which will be applicable to Federal facilities. As an example, the General Conformity threshold for carbon monoxide will be 100 tons per year. The proposed test would release about 0.4 ton.

\subsubsection{Air Contaminant Concentrations}

Concentrations of air contaminants were estimated using the EPA air dispersion model, INPUFF 2.0 (Peterson and Lavdas, 1986). Initial concentrations of pollutants in the rocket plume are presented in Appendix B, Subsection 1.2. Most of the initial concentrations would exceed safe exposure levels for workers. Initial concentrations would rapidly disperse, however, and hazard radii and safe worker reentry times were computed for various wind conditions. For the proposed Side-On tests, the air quality hazard radius is $100 \mathrm{~m}(328 \mathrm{ft}$ ), and the safe worker reentry time is four minutes. For the proposed End-On tests, the hazard

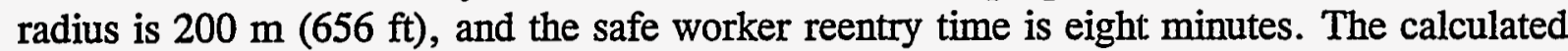
hazard radii and safe worker reentry times are based on atmospheric conditions least favorable to dispersal, for example, low wind speed. Computed hazard radii are smaller than the GHA radius administratively established for these tests. Accordingly, potential worker exposure to air quality impacts would be minimized.

\subsubsection{Impacts of the No Action Alternative}

Under the No Action Alternative, the tests described in the Proposed Action would not take place. Air quality impacts would not occur.

\subsection{WASTE DISPOSAL}

\subsubsection{Impacts of the Proposed Action}

Wastes that are generated by the Proposed Action would be managed by the SNL Waste Management Organization. The amount of waste generated by the Proposed Action would be roughly 20 percent of that amount annually generated by normal operations at the Sled Track. This waste is a small fraction of the total waste generated at SNL and would be easily assimilated by existing waste handling procedures.

The quantity of RCRA-regulated hazardous waste generated by the Proposed Action is estimated to be $5 \mathrm{~kg}(11 \mathrm{lb})$; this represents 0.003 percent of the average annual SNL total 
of $150,000 \mathrm{~kg}$ (34 tons) per year (SNL, 1993). There are no addition impacts by the Proposed Action to the SNL waste management processes.

\subsubsection{Impacts of the No Action Alternative}

Under the No Action Alternative, the tests described in the Proposed Action would not take place. The incremental waste would not be generated.

\subsection{ACCIDENT SCENARIOS}

\subsubsection{Impacts of the Proposed Action}

\subsubsection{Dispersal of Depleted Uranium}

As evaluated in Appendix A, Subsection 5.5, an unexpected test outcome, such as the total destruction of the RTG section, could cause release a maximum of $3.6 \mathrm{~kg}(7.9 \mathrm{lb})$ of depleted uranium oxide. There is no expectation that such an event would occur. Stated in terms of the radiation dose that would be received by workers, their exposure would increase by 79 percent. Using a dose-to-risk conversion factor of $4 \times 10^{-4}$ latent cancer fatalities per person-rem, the additional risk of cancer to the project personnel as the result of this program would increase from one in 10,000 to one in 5,600. Another way to state this risk estimate is that risk would increase from one additional fatal cancer for every 10,000 programs of this magnitude to one in 5,600 programs. It is likely in such an accident that much of the depleted uranium oxide at least would be partially contained and would remain in pieces large enough to be identified and collected; therefore, the amount of residual depleted uranium probably would be much smaller and the cancer risk also would be lessened. Even if this release were to occur, the radiation exposure would be about 300 times smaller than the DOE 5-rem exposure limit for radiation workers. Toxicological exposure would be about 286 times smaller than the ACGIH standard for airborne exposure to workers. No exposure to uninvolved workers or off-site exposure to the general public would be expected.

\subsubsection{Methanol Spill}

Test preparations would require small amounts of organic solvents for miscellaneous purposes such as spot cleaning surfaces prior to applying an adhesive. Most products are in 3.8 liter (1 gallon) or smaller containers, including methanol, methyl ethyl ketone, toluene, tape drive head cleaner, electronics spray cleaner, and denatured alcohol. Since chemical use is small, the level of exposure to workers would be minimal; no exposure to uninvolved workers or off-site exposure to the public would be expected. A spill of the entire contents of a container would represent a credible situation that would create the greatest exposure to personnel. However, even spillage of an entire container of any of these substances is unlikely to cause substantial release to the environment. 
For example, if the entire contents of a one gallon bottle of methanol were spilled in a room with the following dimensions, $7.58 \mathrm{~m}(25 \mathrm{ft})$ by $12.3 \mathrm{~m}(40 \mathrm{ft})$ by $2.73 \mathrm{~m}(9 \mathrm{ft})$, the vapor level would be about 8,940 parts per million (ppm). This concentration exceeds the OSHA and ACGIH standards; however, it is unlikely that this exposure has the potential to cause damage to eye sight. The peak blood methanol level would be estimated to be 29.95 milligrams per 100 milliliters of blood. An initial blood level in excess of $100 \mathrm{mg} / 100 \mathrm{ml}$ would be required for irreversible effects such as damage to the eyes and optic nerve to occur (Casarett and Doull, 1993). Methanol also is a flammable liquid and can form explosive mixtures. Even if one gallon of methanol were to be spilled, the resultant average concentration of 8,941 ppm would be less than the Lower Explosive Limit (LEL) of 6 percent $(60,000 \mathrm{ppm})$.

In the situation in which a gallon container is accidentally broken, personnel would seek to contain the spill and call the appropriate hazardous response team for clean up assistance. These actions would reduce personnel exposure. No release to the environment through floor drains or similar pathways would be expected.

\subsubsection{Transport Between LANL and SNL}

Test articles containing depleted uranium oxide would be transported between LANL and SNL by commercial vehicle. The one-way distance between the two sites is approximately $163 \mathrm{~km}(101 \mathrm{mi})$. The average truck accident rate for the U.S. is 3.1 accidents per $10,000,000 \mathrm{~km}$ (6.21 million miles) (DOE, 1993c). The likelihood of an accident would be approximately one in every 20,000 one-way trips. Therefore, an accident is unlikely. Even if an accident were to occur, it is unlikely that depleted uranium oxide would be dispersed into the environment because the material is chemically stable and would be transported in accordance with DOT regulations that specify packaging and container requirements. The shipping manifest would identify the shipper; the proper emergency response team would be notified.

\subsubsection{Impacts of the No Action Alternative}

Under the No Action Alternative, the tests described in the Proposed Action would not take place. The accidents described would not occur. 
This page intentionally left blank. 


\subsection{AGENCIES AND PERSONS CONSULTED}

\begin{tabular}{ll}
\hline \multicolumn{1}{c}{ Person and Agency } & Subject \\
\hline State of New Mexico & \\
Department of Game and Fish & Biological Assessment \\
Bob Wilson & \\
Department of Energy, Minerals, and & \\
Natural Resources-Forestry and & \\
Resource Conservation Division & \\
Robert Sivinsky & Status of Grama Grass cactus \\
Department of Finance and Human & \\
Services-Office of Cultural & \\
Affairs-Historic Preservation & \\
Division & \\
\hline
\end{tabular}

State Historic Preservation

Cultural resource assessment

Officer-Dan Reiley

U.S. Department of the Interior

Fish and Wildlife Service

Ecological Services

Jennifer Fowler-Propst Biological assessment

Pueblo of Isleta

Lt. Gov. Holguin Status of land use agreement

Albuquerque/Bernalillo County Air

Quality Control Board

Dan Warren

Current $\mathrm{ABC} / \mathrm{AQCB}$ regulations 
This page intentionally left blank. 


\section{LIST OF REFERENCES}

ACGIH, 1993, 1993-1994 Threshold Limit Values for Chemical Substances and Physical Agents and Biological Exposure Indices, American Conference of Governmental Industrial Hygienists, Technical Affairs Office, 6500 Glenway Ave., Cincinnati, OH, 1993.

Casarett and Doull, 1993, Toxicology: The Basic Science of Poisons, Fourth Edition, McGraw-Hill, Inc, New York City, 1993.

Cull, Theresa A., 1989, General-Purpose Heat Source Development: Extended Series Test Program Large Fragment: Tests, LA-11597-MS, UC-713, Los Alamos National Laboratory, Los Alamos, New Mexico, August 1989.

CPIA, 1969, Chemical Propulsion Information Agency, Manual CPIAM 1, Johns Hopkins University, Applied Physics Laboratory, Laurel, Maryland, July 1999.

DOC, 1991, 1990 U.S. Census Report, U.S. Department of Commerce, Bureau of the Census, Washington, D.C., 1991.

DOE, 1979, Final Environmental Impact Statement, Los Alamos Scientific Laboratory Site, DOE/EIS-0018, December, 1979.

DOE, 1990, Buffer Zone Agreement, Lease No. 4203188994 with the U.S. Department of . Interior, Bureau of Indian Affairs, Albuquerque, NM, 29 June 1990.

DOE, 1991a, Memorandum of Understanding Between the Department of Energy and the National Aeronautics and Space Administration Concerning Radioistope Power Systems for Space Missions, signed by Richard H. Truly and James D. Watkins, dated July 26, 1991.

DOE, 1991b, Environmental Assessment for Radioisotope Heat Source Fuel Processing and Fabrication, DOE/EA 0534, U.S. Department of Energy, Offices of Special Programs, Assistant Secretary for Space and Energy Systems, Washington, D.C., July 1991.

DOE, 1993a, Residual Radiation Materials Guidelines (RESRAD) Version 5.19 and Manual for Implementing Residual Radioactive Material Guidelines Using RESRAD, Version 5.0, Environmental Assessment Division, Argonne National Laboratories, Argonne, Illinois, September 1993.

DOE, 1993b, Recommendation for the Preparation of Environmental Assessments and Environmental Impact Statements, Office of NEPA Oversight U.S. Department of Energy, Washington, D.C., May 1993. 


\section{LIST OF REFERENCES (Continued)}

DOE, 1993c, Environmental Assessment of the Import of Russian Plutonium-238, DOE/EA0841, U.S. Department of Energy, Office of Nuclear Energy, June, 1993.

DOE, 1993d, Aqueous Sieving of Uranium Oxide Samples, DOE Checklist/Action Description Memorandum, LAN-93-049, September 16, 1993.

DOE, 1994a, Qualification Trials for General-Purpose Heat Source Testing at the 10,000Foot Sled Track, DOE Checklist/Action Description Memorandum, SNA 95-020, December 15, 1994.

DOE, 1994b, Letter CON \#1006, R. J. Hemler, dated August 24, 1994, "Selection of Test Parameters for Fragment Test - Cassini”, DOE, Washington, DC, September 23, 1994.

EPA, 1985. Compilation of Air Pollution Emission Factors, 4th Edition. U.S. Environmental Protection Agency, AP-42, Vol. 1, September 1985.

EPA, 1991. National Primary and Secondary Ambient Air Quality Standards, 40 CFR 50/

ERDA, 1977, Environmental Impact Assessment Sandia National Laboratories, EIA/MA 77-1, Sandia National Laboratories, Energy Research \& Development Administration, Division of Military Application, May 1977.

George, T. G., 1987, General-Purpose Heat Source Safety Verification Test Program: EdgeOn Flyer Plate Tests, LA-10872-MS, UC-33A, Los Alamos National Laboratory, Los Alamos, New Mexico, March 1987.

Hoagland, Steven R., 1990, A Cultural Resources Survey and Review for Sandia National Laboratories, Area III, Kirtland Air Force Base, New Mexico, Chambers Group, Inc., Albuquerque, NM 1990.

Hoagland, Steven R., 1992, Archaeological Surveys for the Coyote Canyon Test Complex, Sandia National Laboratories, Bernalillo County, New Mexico, Prepared for Sandia National Laboratories Coyote Canyon Test Complex Draft Environmental Assessment, Physical Science Laboratory, New Mexico State University, June 1992.

I.C.B.O., 1988, Uniform Building Code, 1988 Edition, International Conference of Building Officials, Whittier, CA, 1988.

Miller, Richard K., 1980, Noise Control Solutions for the Construction Industry, The Fairmont Press, Inc.

NM, 1992, New Mexico Ambient Air Quality Standards and Regulations, New Mexico Environment Department, Air Quality Bureau, Sante Fe, NM, April 14, 1992. 


\section{LIST OF REFERENCES (Continued)}

OSHA, 1989, General Industry Standards, Title 29 Code of Federal Regulations Part 1910, Washington, D.C., 1989.

Peterson, William B., and Lee Lavdas, 1986, INPUFF 2.0: A Multiple Source Gaussian Puff Dispersion Algorithm User's Guide, U.S. Environmental Protection Agency Report 600/8-86/024.

Sanford, A. R., A. J. Budding, J. P. Hoffman, O. S. Alptekin, C. A. Rush, T. R. Toppozada, 1972, Seismicity of the Rio Grande Rift in New Mexico, New Mexico Bureau of Mines and Mineral Resources, Circular 120, Albuquerque, NM, 1972.

SNL, 1983, Sandia National Laboratories Site Development Testing Facilities/Capabilities, SAND 83-0169, Sandia National Laboratories, Albuquerque, New Mexico, October 1983.

SNL, 1991, Sandia National Laboratories, Environment, Safety, and Health Manual, MN47001, Albuquerque, New Mexico, 28 February 1991.

SNL, 1992a, SAND92-2343, Process Assessment Guidance Manual, Sandia National Laboratories, Albuquerque, NM, 1992.

SNL, 1992b, Sandia National Laboratories, Environmental Baseline Update, IT Corporation Project Number 301182.56.01, Albuquerque, New Mexico, May 1992.

SNL, 1993, SAND93-1448, 1992 Environmental Monitoring Report, Sandia National Laboratories, Albuquerque, NM, 1993.

SNL, 1994, Safety Assessment for the 10,000-Foot Sled Track Facility, Gary L. West Organization 2701, Sandia National Laboratories, Albuquerque, NM, October 1, 1994.

Sullivan, Robert M., and Paul J. Knight, 1994, Biological Surveys for the Sandia National Laboratories Coyote Canyon Test Complex, Kirtland Air Force Base, Albuquerque, New Mexico, SAND 93-7089, May 1994. 
This page intentionally left blank. 


\section{APPENDIX A-POTENTIAL EFFECTS ON HUMAN HEALTH AND SAFETY}

\subsection{BACKGROUND INFORMATION}

Potential human health consequences of the Proposed Action are assessed using the following standards:

- Standards established by the U.S. Environmental Protection Agency (EPA)

- Standards of the American Conference of Governmental Industrial Hygienists (ACGIH) and the U.S. Department of Labor Occupational Safety and Health Administration (OSHA)

- Standards of the U.S. Nuclear Regulatory Commission (NRC) are used to assess consequences of radiological materials and exposure

- DOE microcomputer model, Residual Radioactive Materials Guidelines (RESRAD) Version 5.19, and its companion manual, Manual for Implementing Residual Radioactive Material Guidelines Using RESRAD, Version 5.0 are used to evaluate impacts of radioactive soils on the assessment of personnel radiation dosage (DOE, 1993a)

In the evaluation of the potential impacts on human health and safety, special emphasis is placed on health effects of individuals belonging to the following categories: individuals who are involved in the tests described in the Proposed Action; individuals who work at the Sled Track facility, but who are not involved in the Proposed Action; and members of the general public.

\subsection{TERMINOLOGY}

The length of exposure to potential impacts such as noise usually are variable during the workday. Health and safety standards take this variability into account and allow an employee's exposure to be averaged over time (usually for eight hours). The following is an interpretation of ACGIH and OSHA terminology on the averaging times typically used in these standards and also used in this EA (ACGIH, 1993; OSHA, 1989).

- ACGIH Threshold Limit Value (TLV)-Time-Weighted Average (TWA) and OSHA Permissible Exposure Limit (PEL)-TWA

This is the amount of exposure such as to an airborne chemical or to a noise by an employee, for a normal 8-hour workday and a 40-hour work week, to which nearly all workers may be repeatedly exposed, day after day, without adverse effect. This is usually expressed in a ratio of chemical to air in parts per million (ppm) or in milligrams of chemical as measured per cubic centimeter of air $\left(\mathrm{mg} / \mathrm{m}^{3}\right)$.

- Short Term Exposure Limit (TLV-STEL)

This is an amount of exposure to an airborne chemical averaged over 15-minute period which shall not be exceeded at any time during a work day. This is usually expressed in $\mathrm{ppm}$ or $\mathrm{mg} / \mathrm{m}^{3}$. 


\section{In addition, the ACGIH further adds to this definition:}

Exposures up to the STEL should not be longer than 15 minutes and should not occur more than four times per day. There should be at least a 60 -minute break between successive exposures in this range.

- Ceiling Limit Value

The maximum concentration of an airborne contaminant that employees should be exposed during any part of the work day.

\subsection{DEFINITION OF GROUND HAZARD AREAS}

SNL has a rigorous safety and health program in place to assure compliance with appropriate regulations. For an EA, this fact alone is not sufficient to dismiss potential impacts. However, pertinent elements of the SNL safety and health program are directly relevant to limiting impacts. One such element is the rule to establish Ground Hazard Areas (GHA) for different test operations or activities at SNL. A GHA is a delineated area around a test site that is intended to restrict unauthorized personnel from potentially hazardous operations. GHAs at the Sled Track are as follows:

1) For attaching sleds loaded with rockets to the track, the GHA is the oval-shaped area within $381 \mathrm{~m}(1,250 \mathrm{ft})$ in any direction from the track.

2) For attaching ignitors, the GHA is a circular area within a radius of $381 \mathrm{~m}(1,250 \mathrm{ft})$ from the rocket sled, plus a cone shaped-area extending from the track south to the Technical Area III boundary.

3) For impact tests, the GHA is a circular area with a radius of $412 \mathrm{~m}(1,350 \mathrm{ft})$ radius centered at a point $412 \mathrm{~m}(1,350 \mathrm{ft})$ from the south end of the track.

Test areas such as the Sled Track use combinations of warning lights and signs, spotters, fences, and gates to restrict personnel when hazardous operations are in progress. GHAs are particularly useful as a buffer zone for individuals who are unfamiliar with the nature of potentially harmful tests.

\subsection{DEPLETED URANIUM BACKGROUND INFORMATION}

\section{Chemical Toxicity}

Depleted uranium is considered a toxic heavy metal. The effects of uranium exposure are a function of particle size and solubility in the human body. Exposure to depleted uranium occurs primarily from inhalation of respirable particles. Secondary ingestion of particles also is possible.

Uranium forms a variety of uranium salts that often are more soluble and toxic than metallic uranium compounds. Uranium salts are systemic poisons, rapidly absorbed by the body, typically producing severe kidney damage with the severity depending upon the level of exposure. While insoluble compounds may be considered less toxic, they are retained in the 
body longer and are capable of producing lung disease such as fibrosis and lung cancer (Casarett and Doull, 1993).

Exposure standards published by OSHA and ACGIH are based primarily on the toxicity of uranium as a chemical and not on its radiation contribution. OSHA and ACGIH TWA exposure limits for soluble uranium compounds in air are $0.05 \mathrm{mg} / \mathrm{m}^{3}$ and $0.2 \mathrm{mg} / \mathrm{m}^{3}$ respectively, whereas exposure limits for insoluble uranium compounds are $0.2 \mathrm{mg} / \mathrm{m}^{3}$ in air. Because only insoluble uranium compounds would be involved in testing under the Proposed Action, limits for insoluble compounds are used in the following assessment of impacts to personnel from depleted uranium.

\section{Radiological Hazards}

Depleted uranium has a specific activity of 0.548 microCuries per gram $(\mu \mathrm{Ci} / \mathrm{g})$ and is, therefore, only weakly radioactive. For insoluble uranium compounds, however, the radioactivity should not be entirely discounted because insoluble uranium particles can be retained in the lungs for long periods of time before the body is able to eliminate this material.

Radiation emitted by depleted uranium is hazardous primarily when respirable particles are inhaled and retained in the lung. Damage in the human body results from the amount of energy transferred by ionizing radiation (alpha, beta, and gamma). Exposure from internal radiation by inhaled particles is considered to be potentially more serious than equal levels of external radiation because exposure continues even when the individual has left the contaminated area and inhaled particles are in close contact with sensitive tissues.

Occupational radiation standards for SNL are published in Chapter 8 of SNL's ES\&H Manual (SNL, 1991). The levels are shown in Table A-1. 
Table A-1. Radiation Protection Standards-Limiting Values for Assessed Dose from Exposure of Occupational Workers and the General Public to Radiation

\author{
Stochastic Effects ${ }^{\mathrm{a}}$ \\ Whole Body \\ 5 rem (annual dose equivalent) \\ Nonstochastic Effects ${ }^{\mathrm{b}}$ \\ Lens of Eye \\ 15 rem (annual dose equivalent) \\ Extremity \\ 50 rem (annual dose equivalent) \\ Skin of the Whole Body \\ $50 \mathrm{rem}$ (annual dose equivalent) \\ Organ or Tissue \\ $50 \mathrm{rem}$ (annual dose equivalent) \\ Unborn Child \\ Entire Gestation Period \\ 0.5 rem (annual dose equivalent)

\section{General Public} \\ Internal \\ Any Tissue \\ 0.1 rem (committed effective dose \\ equivalent) \\ $0.5 \mathrm{rem}$ (including skin and eyes)
}

a Defined as malignant and hereditary disease for which the probability of an effect occurring, rather than its severity, is regarded as a function of dose without threshold.

b Effects such as opacity of the lens of the eye for which the severity of the effect varies with the dose, and for which a threshold may therefore occur.

Data Source: SNL (1991)

\title{
5.0 IMPACTS FROM DEPLETED URANIUM
}

Earlier tests at the LANL have shown that GPHS modules would not rupture as a consequence of these tests causing depleted uranium oxide to be released outside of the sealed iridium cladding and carbon composite GPHS module shells (George, 1987). There is no expectation that personnel would be exposed to depleted uranium oxide from the test articles proposed to be tested. However, worker exposure could arise from residual depleted uranium in the soil at the Sled Track. Accordingly, this subsection will discuss potential effects on workers from normal operations as well as potential exposure to depleted uranium oxide caused by an unforeseen accident.

Much of the test preparation work would take place at the Sled Track impact area. The soil in this area is known to be contaminated with depleted uranium residues from previous test activities. Dust would be generated through the action of vehicles, construction equipment, and the natural action of wind. Personnel in the contaminated area would be exposed primarily through two mechanisms: contact with contaminated soil and through inhalation or ingestion of contaminated dust. Test preparations that might lead to exposure would consist of vehicular movement on unpaved areas, removing test debris, and erecting the 
metal sled barrier and concrete target at the end of the track. A packed soil embankment on three sides of the concrete target would act as a backstop to hold the concrete target in place for the End-On tests. Some repair of these facilities would be likely after each test. These activities would produce a minimal amount of disruption, and the possibility must be considered that personnel would be exposed to depleted uranium from contaminated soil. Personnel not involved with the tests would not be allowed into the test area.

Depleted uranium is a toxic, carcinogenic, radioactive chemical. The level of depleted uranium in the soil at the Sled Track is an important factor in assessing these impacts. Using known levels of site contamination, estimates of human exposures were made. This was accomplished by (1) projecting the amount of dust that would be generated by the proposed activities, (2) calculating the amount of radioactivity that.would be present on the basis of the depleted uranium content in the soil and the estimated airborne dust levels, and (3) making an assumption of the length of exposure.

\subsection{PREVIOUS SITE EVALUATIONS}

A 1992 study was conducted to investigate the extent of uranium contamination at the Sled Track. Five hundred eighty-one samples were collected and analyzed for total uranium. While the analytical method did not distinguish depleted uranium from natural uranium, soil samples indicated the presence of an uranium content elevated above background levels of off-site soil. This elevated uranium level was attributed to depleted uranium released by previous test activities. During this study, SNL personnel collected material identified as depleted uranium for disposal. To be conservative, the uranium content of soil before collection was used as the basis of the following analysis.

Table A-2 summarizes the results of this sampling program. Information in Table A-2 is used to estimate personnel exposure to airborne depleted uranium particulates based on projected dust levels for two hypothetical exposure periods.

Table A-2. Soil Sample Summary

\begin{tabular}{lcc}
\hline & $\begin{array}{c}\text { Total Uranium } \\
\text { Content of Soil } \\
(\mu \mathrm{g} / \mathrm{g})\end{array}$ & $\begin{array}{c}\text { Equivalent Radioactivity of } \\
\text { Soil }^{\mathrm{b}} \\
(\mathrm{pCi} / \mathrm{g})\end{array}$ \\
\hline Range of Values & $<0.08$ to 560 & $<0.04$ to 307 \\
Average Value & 4.71 & 2.58 \\
Standard Deviation & 55.9 & 30.6 \\
\hline
\end{tabular}

a Number of samples is 581

b Conversion factor for one gram of depleted uranium is 0.548 picoCuries per gram (pCi/g)

SNL has taken additional actions to remove easily recoverable depleted uranium test debris and some contaminated soil from the Sled Track area. This effort reasonably is expected to 
have reduced the radioactivity level below those levels measured in 1992. Consequently, impacts to personnel from soil-borne depleted uranium should be more conservative than estimated in the following calculations.

\subsection{EVALUATION OF POTENTIAL AIRBORNE URANIUM CONCENTRATIONS}

An exposure estimate has been made based on information both in Table A-2 and estimated dust levels potentially generated by anticipated activities at the Sled Track. Dust levels were derived using methodology developed by the EPA for industrial paved roads and industrial dust emissions (EPA, 1985). A range of airborne uranium concentrations to which personnel might be exposed was found by multiplying the dust concentrations by the depleted uranium levels in the soil.

In computing a range of airborne concentrations, high and low uranium values were selected that are representative of the range of uranium levels in the soil. A value of $60.62 \mu \mathrm{g} / \mathrm{g}$ was selected to calculate the upper boundary of the range. The value equals the sample mean, plus one standard deviation above the mean, for the total of the samples. The analytical detection limit of $0.08 \mu \mathrm{g} / \mathrm{g}$ was used as the lower boundary. Table A-3 shows calculated values for the concentrations of uranium in air contained in dust raised by wind and vehicles.

Table A-3. Projected Airborne Uranium Concentrations

\begin{tabular}{cccc}
\hline & $\begin{array}{c}\text { Range of Dust Concentrations in } \\
\text { Air Based on Soil Mechanics } \\
\text { and Climatology Parameters } \\
\left(\mu \mathrm{g} / \mathrm{m}^{3}\right)\end{array}$ & $\begin{array}{c}\text { Airborne Uranium }\left(\text { in } \mu \mathrm{g} / \mathrm{m}^{3}\right) \\
\text { when Soil Concentration is }\end{array}$ \\
\cline { 3 - 4 } Source & 560 & $0.08 \mu \mathrm{g} / \mathrm{g}$ & $60.62 \mu \mathrm{g} / \mathrm{g}$ \\
\hline & 4,500 & $4.4 \times 10^{-5}$ & 0.034 \\
Wind, $12 \mathrm{mph}$ & 14,000 & $3.6 \times 10^{-4}$ & 0.273 \\
& 62,500 & 0.0011 & 0.85 \\
Wind, $60 \mathrm{mph}$ & 29,000 & 0.005 & 3.79 \\
& 34,000 & 0.0023 & 1.76 \\
Vehicular traffic & & 0.0027 & 2.06 \\
\hline
\end{tabular}

\subsection{EVALUATION OF CHEMICAL TOXICITY}

To make a useful comparison between the airborne uranium particulates in Table A-3 and OSHA and ACGIH standards for chemical toxicity, several scenarios were developed to bring the potential of exposure into perspective. Table A-4 shows two conceivable scenarios in which personnel would be exposed to airborne uranium as a result of wind- and vehicle-generated dust. For each scenario, concentration levels are calculated into a time-weighted average exposure. A range of soil conditions and meteorological factors from Table A-3 were used to provide high and low values in the dispersion model. 
The first scenario assumes high values of airborne uranium level. This scenario involves personnel working downwind from the contaminated area with an assumed $5.4 \mathrm{~m} / \mathrm{s}(12 \mathrm{mph})$ wind producing $0.273 \mu \mathrm{g} / \mathrm{m}^{3}$ of airborne uranium particulate for 7.5 hours. Also, it is assumed that for a total of 30 minutes daily, vehicles would be driven through the area, raising the airborne content by $2.06 \mu \mathrm{g} / \mathrm{m}^{3}$. Combining these values produces the highest estimate of exposure for an 8-hour workday. The second scenario uses the same wind speed and time periods, but assumes lower values for airborne uranium levels.

\section{Table A-4. Time-Weighted Averages for Uranium Exposure}

\begin{tabular}{|c|c|c|c|}
\hline $\begin{array}{l}\text { Length of } \\
\text { Exposure } \\
\text { (T) } \\
\end{array}$ & $\begin{array}{l}\text { Level of } \\
\text { Exposure } \\
\left(\mu \mathrm{g} / \mathrm{m}^{3}\right)(C) \\
\end{array}$ & $\begin{array}{c}\text { Time-Weighted Average }^{\mathrm{a}} \\
\text { Exposure } \\
\left(\mu \mathrm{g} / \mathrm{m}^{3}\right)\end{array}$ & $\begin{array}{c}\text { OSHA and ACGIH } \\
\begin{array}{c}\text { Standards } \\
\left(\mu \mathrm{g} / \mathrm{m}^{3}\right)^{\mathrm{b}}\end{array} \\
\end{array}$ \\
\hline \multicolumn{4}{|c|}{ \% } \\
\hline 7.5 hours & 0.273 & & \\
\hline 0.5 hours & 2.06 & 0.39 & 200 \\
\hline \% & ?.e & $2 \%$ & $\%$ \\
\hline 7.5 hours & 0.034 & & \\
\hline 0.5 hours & 1.76 & 0.14 & 200 \\
\hline
\end{tabular}

a Time-weighted average is calculated as the average exposure over an 8-hour day by the formula

$$
\frac{\sum_{1}^{N} C T}{8 \text { hours }}
$$

where $C$ is the uranium concentration and $T$ is the time of exposure to the uranium concentration in hours.

b Exposure standards assume that uranium is in an insoluble metallic form.

Table A-4 shows that these scenarios produce average exposures that would be well below the OSHA and ACGIH standards. These scenarios indicate that directly involved personnel would not be exposed to harmful levels from depleted uranium deposited in the soil by previous testing.

\subsection{EVALUATION OF RADIOACTIVITY}

One approach to examining potential radiological health effects is to apply the RESRAD code developed by Argonne National Laboratory (DOE, 1993a). Under current NRC regulations, land contaminated with radioactive materials may be diverted to other uses if the aggregate of all sources of radiation exposure to individuals using the area for a new purpose would produce a dose not exceeding 100 milliroentgen equivalent man per year (mrem/yr). The 
RESRAD model considers direct exposure and inhalation. It is noted that application of the exposure criterion from the NRC regulation requires precise information on all potential radiation exposures.

Using RESRAD, it is straightforward to estimate radiation exposure to individuals who would spend varying amounts of time and perhaps be exposed to airborne dust within the area. The amounts of airborne dust present in the Sled Track area would vary based on seasonal precipitation and wind conditions. In addition, airborne dust amounts will vary depending on the level of human disturbance, especially vehicular movement. To account for the likely range of these variations, several scenarios were formulated for analyzing a wide range of potential dust concentrations. These scenarios also include varying time of exposure of workers at the Sled Track. Table A-5 summarizes seven scenarios and also displays a possible resultant radiation dose computed by applying the RESRAD formulation.

For small scale projects, DOE specifies the dose-to-risk conversion factor for estimating cancer deaths from exposure to low dose rates of ionizing radiation is 400 cancer deaths (latent cancer fatalities) per million person-rem $\left(4 \times 10^{-4}\right.$ deaths per person-rem) (DOE, 1993b). 
Table A-5. Potential Radiation Doses and Health Risks to Workers under the Proposed Action ${ }^{\text {a }}$

\begin{tabular}{|c|c|c|c|}
\hline $\begin{array}{c}\text { Dust Level } \\
\left(\mu \mathrm{g} / \mathrm{m}^{3}\right)\end{array}$ & $\begin{array}{c}\text { Activity Level } \\
(\mathrm{pCi} / \mathrm{g})^{\mathrm{b}}\end{array}$ & $\begin{array}{c}\text { Dose } \\
(\mathrm{mrem} / \mathrm{yr})^{c}\end{array}$ & $\begin{array}{r}\text { Individual } \\
\text { Cancer Ris! }\end{array}$ \\
\hline $\begin{array}{l}\qquad 50 \\
\text { (Corresponds to Primary Ambient } \\
\text { Air Quality Standard for yearly } \\
\text { average for particulates) }\end{array}$ & $\begin{array}{l}\quad 2.58 \\
\text { (average in contaminated } \\
\text { area) }\end{array}$ & 0.031 & $1.2 \times 10^{-8}$ \\
\hline $\begin{array}{l}\qquad 4,500 \\
\text { (Resulting from very dry soil with } \\
\text { wind speed at threshold necessary } \\
\text { to raise dust) }\end{array}$ & $\begin{array}{l}\quad 2.58 \\
\text { (average in contaminated } \\
\text { area) }\end{array}$ & 0.78 & $3.1 \times 10^{-7}$ \\
\hline $\begin{array}{l}\qquad 4,500 \\
\text { (Resulting from very dry soil with } \\
\text { wind speed at threshold necessary } \\
\text { to raise dust) }\end{array}$ & $\begin{array}{l}\quad 33.2 \\
\text { (average measured value } \\
\text { plus one standard devia- } \\
\text { tion, i.e., }>80 \% \text { of all } \\
\text { measured values) }\end{array}$ & 5.5 & $2.2 \times 10^{-6}$ \\
\hline $\begin{array}{l}\qquad 34,000 \\
\text { (Resulting from major surface } \\
\text { disturbance of very dry soil) }\end{array}$ & $\begin{array}{l}\quad 2.58 \\
\text { (average in contaminated } \\
\text { area) }\end{array}$ & 5.8 & $2.3 \times 10^{-6}$ \\
\hline $\begin{array}{l}\quad 34,000 \\
\text { (Resulting from major surface } \\
\text { disturbance of very dry soil) }\end{array}$ & $\begin{array}{l}\qquad 33.2 \\
\text { (average measured value } \\
\text { plus one standard devia- } \\
\text { tion, i.e., }>80 \% \text { of all } \\
\text { measured values) }\end{array}$ & 40.6 & $1.6 \times 10^{-5}$ \\
\hline
\end{tabular}

\footnotetext{
a assumes a two-month program (320 working hours in the Sled Track impact area)

b picoCuries per gram

c milliroentgen equivalent man per year (mrem/yr)
}

The cumulative worker dose would not exceed 0.25 person-rem and the individual dose would not exceed $20 \mathrm{mrem}$. This is based on a work force of 15 people. Four of the individuals would be performing manual labor such as placing targets that would produce exposure from dust. Eleven of the individuals would be present periodically in the impact zone. The testing would be expected to last two month. Using the dose-to-risk conversion factor of $4 \times 10^{-4}$ latent cancer fatalities per person-rem, the additional risk of cancer to the project personnel as the result of this program would be one in 10,000. Another way to state this risk estimate is that one additional fatal cancer would be expected for every 10,000 programs of this magnitude.

\subsection{EVALUATION OF AN ACCIDENT INVOLVING RELEASE OF DEPLETED URANIUM OXIDE}

The maximum amount of depleted uranium oxide that would be used in any one test would be $3.6 \mathrm{~kg}(7.9 \mathrm{lb})$. This amount of uranium oxide would contain $3.2 \mathrm{~kg}(7 \mathrm{lb})$ of depleted 
uranium. If scattered over an area of $100 \mathrm{~m} \times 100 \mathrm{~m} \times 5 \mathrm{~cm}(328 \mathrm{ft} \times 328 \mathrm{ft} \times 2 \mathrm{in})$, $3.2 \mathrm{~kg}(7 \mathrm{lb})$ of depleted uranium would increase the average radioactivity level by approximately $2.2 \mathrm{pCi} / \mathrm{g}$. This level would be approximately $79 \%$ of the average level of soil radioactivity found in the 1992 study. Stated in terms of the radiation dose that would be received by workers, their exposure would increase by 79 percent. Using the dose-to-risk conversion factor of $4 \times 10^{-4}$ latent cancer fatalities per person-rem, the additional risk of cancer to the project personnel as the result of this program would increase from one in 10,000 to one in 5,600 . Another way to state this risk estimate is that risk would increase from one additional fatal cancer for every 10,000 programs of this magnitude to one in 5,600 programs. It is likely in such an accident that much of the depleted uranium oxide at least would be partially contained and would remain in pieces large enough to be identified and collected; therefore, the amount of residual depleted uranium probably would be much smaller and the resulting risk of additional fatal cancers also would be lessened. Because their potential exposure would be much lower than site workers, neither the personnel not directly involved in the proposed test nor the general public would be adversely affected.

\subsection{HEALTH IMPACTS FOR A HYPOTHETICAL SPILL OF METHANOL}

Routine preparations for a sled track test require only small amounts of organic solvents for miscellaneous purposes such as spot cleaning a surface prior to applying an adhesive. The usage rate per chemical is about one gallon per year. Chronic exposure is not anticipated at this low rate of chemical use. A spill of a one gallon container would represent a credible accident situation likely to create an acute exposure.

The following calculations were used to develop the accident scenario if one gallon (3.78 liters) of methanol was spilled. It is assumed that the entire contents of a one gallon bottle is spilled in a room with the following dimensions, $7.58 \mathrm{~m}(25 \mathrm{ft})$ by $12.3 \mathrm{~m}(40 \mathrm{ft})$ by $2.73 \mathrm{~m}$ ( $9 \mathrm{ft})$. The following expression will be used to calculate the vapor level inside this room assuming it completely evaporates and distributes equally.

$$
\mathrm{mg} / \mathrm{m}^{3}=\frac{\text { milligrams of methanol }}{\text { cubic meters of room air volume }}
$$

To determine the concentration in milligrams, the quantity of methanol should be multiplied by the density of methanol $(0.79 \mathrm{~kg} / \mathrm{l})$ which yields

$$
3.785 \mathrm{~L} \times 0.79 \mathrm{~kg} / \mathrm{L} \times 10^{6} \mathrm{mg} / \mathrm{kg}=2.99 \times 10^{6} \mathrm{mg} \text { methanol }
$$

The volume of the room in cubic meters can be calculated by the following expression:

$$
\frac{(25 \mathrm{ft} \times 40 \mathrm{ft} \times 9 \mathrm{ft}) \times 28.32 \mathrm{~L} / \mathrm{ft}^{3}}{1000 \mathrm{~L} / \mathrm{m}^{3}}=254.9 \mathrm{~m}^{3}
$$

The concentration in the room can be calculated to be

$$
\frac{2.99 \times 10^{6} \mathrm{mg}}{254.9 \mathrm{~m}^{3}}=11,739 \mathrm{mg} / \mathrm{m}^{3}
$$


To convert this to $\mathrm{ppm}$, the following formula is used

$$
\frac{11,739 \mathrm{mg} / \mathrm{m}^{3} \times 24.45 \mathrm{~L} / \mathrm{mole}}{\text { molecular weight of } 32.1 \mathrm{~g} / \text { mole }}=8,941 \mathrm{ppm}
$$

The result of this calculation shows that such an event would produce a level of $8,941 \mathrm{ppm}$ of methanol in the room.

Methanol can damage the eyes and the optic nerve if exposure is extensive. An initial blood level in excess of 100 milligram per milliliter of blood $(\mathrm{mg} / \mathrm{ml})$ would be required for irreversible effects to occur (Casarett and Doull, 1993).

According to Casarett and Doull (1993), to determine the significance of this example, the body burden of methanol can be calculated with the following assumptions:

- there is 100 percent absorption of the vapors

- length of exposure is one hour

- the respiratory volume in one hour is $1.25 \mathrm{~m}^{3}$.

$$
11,739 \mathrm{mg} / \mathrm{m}^{3} \times 1.25 \mathrm{~m}^{3} / \text { hour } \times 1.0 \text { hour }=14,674 \mathrm{mg} / \text { hour }
$$

If it is assumed that this total body burden is absorbed within the first minutes of exposure and that the methanol distributes with total body water, a peak blood methanol level may be calculated as follows:

$$
\frac{14,674 \mathrm{mg}}{49 l *}=299.5 \mathrm{mg} / \mathrm{l}=29.95 \mathrm{mg} / 100 \mathrm{ml}
$$

* assumes a $70-\mathrm{kg}$ person with 70 percent water content.

Thus, even though the potential exposure is severe and exceeds the OSHA and ACGIH standards $\left(263 \mathrm{mg} / \mathrm{m}^{3}\right)$, it is unlikely that this brief exposure would causing damage to eye sight or other irreversible, adverse health effects for involved workers. 
This page intentionally left blank. 


\section{APPENDIX B-AIR QUALITY INVESTIGATION}

\subsection{GENERAL}

The primary air quality effect resulting from the Proposed Action would be the release of the rocket exhaust products into the atmosphere. Space heating, vehicles, construction equipment, and electric generators also would release small amounts of air contaminants. Because buildings would be heated and routine use of vehicles would occur whether or not the RTG testing was conducted, emissions from these sources were not included in the analysis.

\subsection{AIR CONTAMINANT AMOUNTS}

Amounts of pollutants that would be emitted during the proposed tests were estimated from the known properties of rocket motors, from EPA emission factors (EPA, 1985), and from estimates of vehicle and generator usage.

\subsubsection{Rocket Motors}

As discussed in Section 2 of the EA, a varying number of Mighty Mouse and HVAR rocket motors would be used to provide impulse for the test sleds. Pertinent information about Mighty Mouse motor and HVAR rocket motors is summarized in Table B-1.

Using data in Table B-1, computations were made to determine the maximum amount of each air contaminant that could be released by rocket booster motors during the RTG testing. The computed results then were compared with New Mexico Significant Emission Rates. These are the threshold annual emission rates for major new or modified air pollution sources at which regulatory requirements for monitoring and for Prevention of Significant Deterioration increments begin to apply. This project is neither a new nor a major pollution source as defined by the regulations, but the annual quantities are a useful guideline for evaluating the air emissions.

Estimates of maximum contaminant concentrations are presented in Table B-2. These estimates are conservative because they are based on both the maximum number of firings that would take place and the maximum number of rocket motors that would be used for any firing. It is likely that fewer firings would be required to accomplish the test goals, and that many of the firings would require fewer than the maximum number of rockets.

Because lead releases have special EPA reporting requirements, an additional evaluation is made. The maximum quantity of lead that would be released by all the tests, $1.78 \mathrm{~kg}$ (3.9 lb), would be less than the EPA reportable quantity, 10 pounds, for a single event. 
Table B-1. Characteristics of Mighty Mouse and HVAR Rocket Motors

\begin{tabular}{lcc}
\hline \multicolumn{1}{c}{ Characteristics } & $\begin{array}{c}\text { Mighty Mouse } \\
\text { Rocket Motor }\end{array}$ & HVAR \\
\hline Propellant mass (kg) & 2.7 & 10.9 \\
Carbon monoxide released (kg) & 1.34 & 4.87 \\
Sulfur dioxide released (kg) & & 0.074 \\
Lead released (kg) & 0.024 & 0.0076 \\
Potassium hydroxide released (kg) & & 0.091 \\
Burn time at $21^{\circ} \mathrm{C}(\mathrm{s})$ & 1.42 & 0.94 \\
Maximum number for a single firing & 3 & 20 \\
Maximum number of firings & 6 & 3 \\
\hline
\end{tabular}

Data Source: CPIA, 1969

Table B-2. Air Contaminants Released by Rocket Motors

\begin{tabular}{llc}
\hline \multicolumn{1}{c}{ Contaminants } & $\begin{array}{c}\text { Maximum Release } \\
\text { (tons) }\end{array}$ & $\begin{array}{c}\text { NM Significant Emission Rate } \\
\text { (tons) }\end{array}$ \\
\hline Carbon monoxide & 0.344 & 100 \\
Sulfur dioxide & 0.0049 & 40 \\
Lead & 0.00090 & 0.6 \\
Potassium hydroxide & 0.0060 & $a$ \\
\hline Total & 0.356 & \\
\hline
\end{tabular}

a Not a criteria pollutant. No significant emission rate established.

\subsubsection{Electrical Generators and Construction Equipment}

Electrical generators could be used during some phases of the testing. Assuming that a single $60-\mathrm{kW}$ Diesel generator would operate for 4 hours per day on one-half of the working days, the total emissions can be computed using emission factors from EPA, 1985. Assuming that 
a single piece of Diesel-powered construction equipment would operate the same amount of time and that the engine emissions would be equal to those from the generator, these emissions also were computed. The combined emissions are reported in Table B-3.

\section{Table B-3. Estimated Emissions of Air Contaminants from Generators and Construction Equipment}

\begin{tabular}{lc}
\hline & $\begin{array}{l}\text { Emission } \\
\text { (kg [tons]) }\end{array}$ \\
\hline Carbon monoxide & $38.1(0.042)$ \\
Particulates & $14.5(0.016)$ \\
Hydrocarbons & $4.35(0.0048)$ \\
Nitrogen oxides & $144(0.16)$ \\
Sulfur oxides & $16.3(0.018)$ \\
\hline
\end{tabular}

\subsubsection{Summary of Air Contaminant Quantities}

The quantities of air contaminants of all major sources associated with the RTG testing are summarized in Table B-4. Quantities of all air contaminants are less than New Mexico Significant Emission Rates.

Table B-4. Air Contaminant Emissions During Test by Contaminant and Source Category

\begin{tabular}{lcccc}
\hline & $\begin{array}{c}\text { Rocket motors } \\
\text { (kg [tons]) }\end{array}$ & $\begin{array}{c}\text { Generators/ } \\
\text { Equipment } \\
\text { (kg [tons]) }\end{array}$ & $\begin{array}{c}\text { Total } \\
\text { (tons) }\end{array}$ & $\begin{array}{c}\text { NM Significant } \\
\text { Emission Rate } \\
\text { (tons) }\end{array}$ \\
\hline Carbon monoxide & $312(0.344)$ & $38.1(0.042)$ & 0.386 & 100 \\
Particulates & & $14.5(0.016)$ & 0.016 & 25 \\
Nitrogen oxides & & $145(0.16)$ & 0.16 & 40 \\
Sulfur oxides & $4.44(0.0049)$ & $16.3(0.018)$ & 0.023 & 40 \\
Lead & $0.816(0.00090)$ & & 0.00090 & 0.6 \\
Hydrocarbons & & $4.35(0.0048)$ & 0.0048 & $40^{2}$ \\
Potassium hydroxide & $5.46(0.0060)$ & & 0.0060 & $\mathrm{~b}$ \\
\hline
\end{tabular}

a Volatile organic compounds as a precursor of ozone.

b Not a criteria pollutant. No significant emission rate established. 


\subsection{AIR CONTAMINANT CONCENTRATIONS}

Concentrations of air contaminants were estimated using EPA air dispersion models. The model INPUFF 2.0 was used to predict the concentrations of contaminants from rocket motors and from generators and construction equipment (Peterson and Lavdas, 1986).

\subsubsection{Rocket Motors}

Concentrations of air contaminants that would result from the firing of rocket motors can be predicted using knowledge of the test conditions as inputs to a dispersion model. These would include the quantity and initial distribution of pollutants. To achieve the proposed test objectives, the speed of the test article or thin aluminum sheet at impact must be accurately controlled, and the motors must burn-out before impact. Test planners would be able to adjust the impact speed by adding weight to the sled assembly.

Calculations performed by the test planners indicate that the two types of sleds used in the Proposed Action would travel relatively short distances while the rockets would be firing. These distances would be a minimum of $60 \mathrm{~m}$ (197 ft) for the Might Mouse-propelled sleds and $145 \mathrm{~m}$ ( $475 \mathrm{ft}$ ) for the HVAR-propelled sleds. If lighter sleds were used, the emissions would be dispersed initially along a longer section of the track; therefore, evaluating the concentrations for the minimum trajectory lengths places an upper bound on short-term average concentrations near the facility. At ignition, the high-speed exhaust plume extends a considerable distance from the motor bodies. For small motors such as the Mighty Mouse motor, the plume extends approximately $15 \mathrm{~m}(50 \mathrm{ft})$. For HVAR motors, the distance is approximately $30 \mathrm{~m}(100 \mathrm{ft})$. Thus, the exhaust products would be dispersed along the track for a distance of at least $75 \mathrm{~m}$ ( $246 \mathrm{ft})$ for the Mighty Mouse firings and $175 \mathrm{~m}(574 \mathrm{ft})$ for the HVAR firings.

An appropriate methodology for estimating the initial concentrations of air contaminants is to treat the release of the rocket exhaust products as hot gases that expand and cool until they reach the ambient temperature of the air. The burn rate of the propellant, and thus the rate of production of air contaminants during the burn, would be approximately constant. To estimate concentrations, the exhaust plume can be arbitrarily divided into a number of equallength segments to approximate the distribution of exhaust products. The plume would be emitted near the ground; as a first approximation, its shape in each segment can be treated as a half-cylinder. The radius can be computed geometrically from the volume. Using this approach, the initial concentrations of air contaminants in the plume can be computed, and these values are presented in Table B-5, along with the ACGIH recommended TLV-TWA. 
Table B-5. Initial Exhaust Plume Air Contaminant Concentrations and TimeWeighted Average Exposure and Excursion Limits

\begin{tabular}{lcccc}
\hline Contaminant & $\begin{array}{c}\text { 20 HVAR } \\
\text { Motors } \\
\left(\mathrm{mg} / \mathrm{m}^{3}\right)\end{array}$ & $\begin{array}{c}\text { Mighty Mouse } \\
\text { motors } \\
\left(\mathrm{mg} / \mathrm{m}^{3}\right)\end{array}$ & $\begin{array}{c}\text { ACGIH- } \\
\text { Recommended } \\
\text { TLV-TWA } \\
\left(\mathrm{mg} / \mathrm{m}^{3}\right)\end{array}$ & $\begin{array}{c}\text { ACGIH- } \\
\text { Recommended } \\
\text { Excursion Limit } \\
\left(\mathrm{mg} / \mathrm{m}^{3}\right)\end{array}$ \\
\hline Carbon monoxide & 180 & 215 & 29 & $145(87)^{\mathrm{a}}$ \\
Lead & 0.272 & 3.89 & 0.05 & $0.25(0.15)^{\mathrm{b}}$ \\
Sulfur dioxide & 2.74 & & 5.2 & $13^{\mathrm{c}}$ \\
Potassium hydroxide & 3.36 & & 2 (ceiling value) & $2^{\mathrm{d}}$ \\
\hline
\end{tabular}

a Following ACGIH recommendations, the absolute exposure limit (145) is five times the TLV-TWA. A TWA of three times the TLV-TWA (87) is permissible for 30 minutes.

b Following ACGIH recommendations, the absolute exposure limit (0:25) is five times the TLV-TWA. A TWA of three times the TLV-TWA (0.15) is permissible for 30 minutes.

c This value is the short-term exposure limit, defined as the maximum 15-minute TWA to which workers should be exposed.

d This value is the ceiling limit, which is the highest instantaneous concentration to which workers should be exposed.

Except for sulfur dioxide, these calculated concentrations would exceed the recommended limits even for short-term exposure. Therefore, the results for the dispersion modeling have been used to calculate the hazard radii and safe worker reentry times. The modeling results have been used to predict the concentrations of pollutants at more distant points.

The EPA computer model INPUFF 2.0 was used to predict the air dispersion because it is more readily adaptable than most models to unusual situations such as the proposed Sled Track tests. It is well suited to the terrain near the Sled Track. As discussed above, the length of track along which the contaminants would be initially dispersed was divided into 10 segments. Because of the acceleration of the sleds, a smaller fraction of the total exhaust contaminants would be deposited in each successive segment. The initial distribution of the contaminants was established and the model was run to provide the distribution as a function of time.

The HVAR motors would produce the highest concentrations of all pollutants, except lead. With very light $(1 \mathrm{~m} / \mathrm{s}$ [2.2 mph]) wind perpendicular to the track, the computer simulation modeling predicts that the carbon monoxide concentration produced by 20 HVAR motors would never exceed $145 \mathrm{mg} / \mathrm{m}^{3}$ on a ten-second average basis at any distance $100 \mathrm{~m}$ (328 ft) or farther from the track. Thus, $100 \mathrm{~m}$ (328 ft) is the computed hazard radius for carbon monoxide exposure.

Similar calculations were made for other contaminants. For lead exposure, the hazard radii would be slightly smaller for levels corresponding to one, three, and five times the 8-hour 
TWA. For sulfur dioxide, a hazardous concentration never would be reached. For potassium hydroxide, the concentration limit of $2 \mathrm{mg} / \mathrm{m}^{3}$ would not be reached for any distance greater than $200 \mathrm{~m}$ (656 ft) from the track. The higher concentrations at the smaller distances all would occur within two minutes of the test event.

After four minutes, the concentrations of all pollutants at all points would drop below the most conservative hazard levels. Thus, a conservative estimate for the hazard radius is $400 \mathrm{~m}$ $(1,312 \mathrm{ft})$, and the time until workers could safely reenter the Sled Track area would be four minutes. Computations were made for other wind directions, and hazard distances and safe worker reentry times were computed to be far less than those for the light wind case. The hazard radii and safe worker reentry times listed above were based on atmospheric conditions least favorable to dispersal. These include wind speed, inversion height, and atmospheric stability. A GHA radius of $412 \mathrm{~m}$ (1,350 ft) would be established for these impact tests, and this GHA radius would assure that personnel would not be subjected to injurious levels of air contaminants.

Compared with the HVAR rocket motors, the Mighty Mouse motors would produce far smaller quantities of carbon monoxide, but would produce larger quantities of lead. Dispersion modeling was performed for these boosters using a maximum of three motors. From air dispersion modeling, it was determined that carbon monoxide concentrations of $145 \mathrm{mg} / \mathrm{m}^{3}$ would not be exceeded for any location more than $100 \mathrm{~m}$ (328 ft) from the track. The carbon monoxide level would be less than $29 \mathrm{mg} / \mathrm{m}^{3}$ at all locations after three minutes.

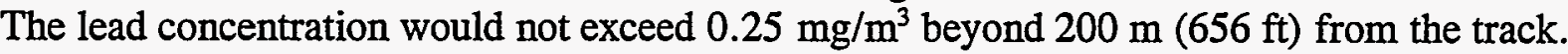
After eight minutes, the concentrations of all pollutants at all points would drop below the most conservative hazard levels.

Additional modeling was performed to predict the concentrations of pollutants at points farther than $500 \mathrm{~m}(1,640 \mathrm{ft})$ from the sled trajectory. The maximum transient concentration of lead at Bldgs. 6741 and 6743 near the center of the track (approximately 1,400 m $(4,600 \mathrm{ft})$ from the sled trajectory) are computed to be less than one percent of the ACGIH TLV-TWA $\left(0.05 \mathrm{mg} / \mathrm{m}^{3}\right)$. The maximum transient concentration of carbon monoxide would be less than the level of the ACGIH TLV-TWA $\left(29 \mathrm{mg} / \mathrm{m}^{3}\right)$. At the Gibson Boulevard entrance to KAFB, the maximum transient concentrations would be less than one tenthousandth of the TLV-TWA. These concentrations would represent an increase over the ambient air concentrations of less than one-tenth of one percent $(0.1 \%)$ of the Federal and New Mexico Ambient Air Quality Standards (NM, 1992; EPA, 1991).

In summary, the maximum air quality hazard radius for any type of test anticipated would be $500 \mathrm{~m}(1,640 \mathrm{ft})$. The maximum time until workers could safely reenter the Sled Track area would be eight minutes. With higher wind speeds, the hazard radii and safe worker reentry times would be reduced. With HVAR motors, the modeling indicates that all pollutant levels would remain below the most conservative hazard concentrations whenever the wind speed is $3 \mathrm{~m} / \mathrm{s}(7 \mathrm{mph})$ or greater. With Mighty Mouse motors, all pollutant levels would remain below the most conservative hazard concentrations whenever the wind speed is $5 \mathrm{~m} / \mathrm{s}(11 \mathrm{mph})$ or greater. 


\subsubsection{Generators and Construction Equipment}

Downwind concentrations of the pollutants were predicted with INPUFF 2.0 for $1 \mathrm{~m} / \mathrm{s}$ wind speed and at a distance of $10 \mathrm{~m}$ from the source and are presented in Table B-6. Because a generator is effectively a point-source, variation in wind direction tends to cause a more rapid reduction in the downwind concentration. This effect was simulated by alternating the wind direct by 30 degrees every two minutes.

Table B-6. Estimated Concentrations at a Downwind Distance of $\mathbf{1 0} \mathrm{m}$ from Generators and Construction Equipment

\begin{tabular}{lcc}
\hline & $\begin{array}{c}\text { Concentration at } 100 \mathrm{~m} \\
\left(\mathrm{mg} / \mathrm{m}^{3}\right)\end{array}$ & $\begin{array}{c}\text { ACGIH 8-hour TWA } \\
\left(\mathrm{mg} / \mathrm{m}^{3}\right)\end{array}$ \\
\hline Carbon monoxide & 0.98 & 29 \\
Particulates & 0.37 & 10 \\
Hydrocarbons & 0.11 & $890^{\mathrm{a}}$ \\
Nitrogen oxides & 3.7 & 5.6 \\
Sulfur oxides & 0.43 & 5.2 \\
\hline
\end{tabular}

a The value for gasoline was used as a proxy because it is a mixture of hydrocarbons

The concentrations of all air contaminants released by generators and construction equipment rapidly disperse and reach insignificant levels within $50 \mathrm{~m}$ (164 ft) of the source. 